\title{
What Does Really Drive Consumer Confidence?
}

\author{
Simona Malovaná ${ }^{1}$ (D) Martin Hodula ${ }^{1,2} \cdot$ Jan Frait ${ }^{1,3}$
}

Accepted: 27 January 2021 / Published online: 13 February 2021

(c) The Author(s), under exclusive licence to Springer Nature B.V. part of Springer Nature 2021

\begin{abstract}
We construct a novel index of households' macroeconomic environment (HOME) based on the data from 22 high-income European countries between 2002 Q1 and 2018 Q4. The resulting index is in line with the broad features of the countries' business and financial cycles and captures well households' perception of their underlying economic situation. We discuss joint properties of the HOME index and the widely employed survey-based consumer confidence indicator. We show that households' expectations are tightly linked to current macroeconomic conditions. This finding echoes the literature linking consumer attitudes and actual economic developments. The HOME index also reflects the importance of asset prices and lending conditions for households' behavior. In a single-country case study, we provide empirical evidence that links the proposed index to new credit extended to households. The evidence suggests that households need a longer period of good macroeconomic conditions to decide to take on a mortgage than they do in the case of a consumer loan.
\end{abstract}

Keywords Composite index · Factor analysis $\cdot$ Households' confidence $\cdot$ Loan growth

JEL Classification F12 $\cdot$ F41 $\cdot$ F43

\section{Introduction}

Following the Global Financial Crisis (GFC), researchers have turned their focus to expectational factors contributing to credit booms while leaving aside the assumptions of rational behavior and rational expectations. Fuster et al. (2010) propose a natural expectations

Simona Malovaná

simona.malovana@cnb.cz

Martin Hodula

martin.hodula@cnb.cz

Jan Frait

jan.frait@cnb.cz

1 Czech National Bank, Na Příkopě 28, 11503 Prague 1, Czech Republic

2 Technical University of Ostrava, Sokolská třída 2416/33, 70200 Ostrava 1, Czech Republic

3 University of Finance and Administration in Prague, Estonská 500, 10100 Prague 10, Czech Republic 
concept. Households tend to have wrong beliefs about the true development of fundamental factors and over-estimate the persistence of favorable conditions. As a result, they can be excessively optimistic in good times and pessimistic in bad times. Boom and bust cycles then follow. Similarly, Bordalo et al. (2018) present a model with diagnostic expectations in which agents tend to overweight future outcomes that they have anticipated in light of current data. Foote et al. (2012) go even further and state that the facts refute the popular story that the GFC resulted from finance industry insiders deceiving uninformed mortgage borrowers and investors. Instead, they argue that borrowers and investors made decisions that were rational and logical given their ex post overly optimistic beliefs about the development of house prices.

The concept of extrapolative expectations-originally developed to explain asset price drifts (Schiller 2000) — clarifies that expectations formed by extrapolating recent trends can become temporarily self-fulfilling. This particular concept can also be applied to households' perceived economic situation. For example, the combination of fast income growth and low interest rates can give rise to optimistic expectations that can be gradually extrapolated to the view that the good times will last "forever". Households can then be inclined to tolerate a much higher level of indebtedness. If these optimistic expectations are accompanied by steady growth in housing prices, the overall level of debt can shoot up in a relatively short period. This way of forming expectations is an outcome of the constrained rationality of households. Households are ready to accept that the fast income growth is just temporary and will converge to more normal levels in the long run. At the same time, households tend to underrate the probability that a period of abnormal income growth will be followed by a subnormal one.

We investigate into key macroeconomic factors affecting households' economic perceptions. To overcome the shortcomings of single indicators such as disposable income, wages, and savings, we propose a composite index that captures the development of the overall macroeconomic conditions faced by households. The index combines eleven macroeconomic variables most commonly found in the literature that jointly drive consumer confidence and expectations. We refer to this index as the Households' Macroeconomic Environment Index (henceforth HOME index). The index is constructed for 22 highincome OECD countries in Europe at quarterly frequency between 2002 and 2018.

Households' perceptions of their economic situation are also influenced by structural factors such as income distribution, participation, demographic patters, etc. These change slowly and are showing their effect mainly in the long-run. We can leave these factors aside without a collateral damage since our focus is short- to medium-term conjunctural development driven by business and financial cycles.

Using the proposed index, we evaluate the relationship between consumer attitudes measured by the consumer confidence index (CCI) published by the OECD and the economic conditions faced by households. We find that the consumer confidence is largely based on the development of macroeconomic fundamentals as evidenced by a reported tight empirical link between the CCI and the HOME index development. Further, our results suggest that-when consumers report on their confidence in a survey-they load on current or very recent economic information which are then pinned down and gradually extrapolated into the future. In this respect, we find empirical support for the view that households' expectations are extrapolative.

In general, we discover that large portion of the information in CCI is already contained in other economic and financial indicators that form our proposed HOME index. Since the CCI loads on current or very recent macroeconomic data, it is subject to the same revisions as macroeconomic aggregates. As a result, it may not have much of a value added for 
policymakers as an additional source of information or as a leading indicator. On the contrary, it may provide a misleading assurance drawn from the evolution of this index which only reflects already observable and measurable trends.

HOME index captures to limited extent the developments of non-fundamental (irrational) households' beliefs through asset prices that often show up strong cyclical swings associated with greed, fear, myopia and extrapolation. By allowing for it, the HOME index similarly to the CCI might also partially reflect on psychological aspects (i.e. animal spirits) which however, are found to be rather short-lived if not met with an actual improvements in economic conditions (Barsky and Sims 2012).

Following recent theoretical literature on credit cycles and the formation of asset bubbles (Nofsinger 2012; De Stefani 2017; Bordalo et al. 2018; Angelico 2018), we provide a single-country case study to offer some deeper understanding of, and economic intuition for, the values of the HOME index and its relationship with credit dynamics. Specifically, we use data for the Czech economy in a dynamic model averaging framework. Our estimates show the HOME index does a very good job in predicting the development of new loans. Further, we find that households generally need a longer period of good macroeconomic conditions to decide to take on a mortgage than they do in the case of a consumer loan.

The remainder of the paper is structured as follows. Section 2 discusses the existing literature. Section 3 presents the methodology and data used to construct the index and provides a comparison of the new index with the OECD consumer confidence index. Section 4 uses the index and investigates empirically its ability to predict the evolution of new loans and consumption expenditure in a case study analysis for the Czech Republic. Section 5 concludes.

\section{Consumer Confidence Indicators: A Short Review}

Empirical studies focused on households' expectations generally rely on consumer confidence indicators, which, in turn, are mostly based on information obtained from household surveys. Consumer confidence surveys, which are regularly conducted in at least 45 countries (Curtin 2007), have been used to provide stakeholders, particularly government policymakers and business leaders, with timely and important information on consumer attitudes and perceptions. Multiple studies have focused on linking consumer confidence and consumption growth. Mishkin (1978) reported that the Index of Consumer Sentiment published by the University of Michigan possesses good explanatory power for changes in durable goods. Acemoglu and Scott (1994) found that consumer confidence is a leading indicator of future consumption growth in the United Kingdom. Delorme et al. (2001) conducted a study on consumer confidence and rational expectations in the United States compared with the United Kingdom. Mehra and Martin (2003) found that consumer confidence is a significant predictor for consumer spending. Using regional data, Garrett et al. (2005) showed that consumer confidence helped in predicting retail spending in the US. Other empirical studies researching the predictive power of consumer confidence indicators include Belessiotis (1996), Kwan and Cotsomitis (2006), Souleles (2004), Vuchelen (2004), and many others.

More recently, researchers have switched their focus to using consumer confidence indicators to explain credit dynamics. Kłopocka (2017) shows that consumer confidence indexes have strong predictive power for future household borrowing. De Stefani (2017) 
documents that expectations of US households contain a component of systematic extrapolative bias which is inconsistent with full-information rational expectations theory. $\mathrm{He}$ shows that a change in house price expectations has substantial effects on mortgage leverage, which increases whenever there is an expected increase in home equity. Angelico (2018) provides empirical evidence that survey data on expectations have strong predictive power for the dynamics of household debt. She shows that beliefs depart from rationality at the aggregate level in a way coherent with the hypothesis of natural expectations. A positive shock to income first generates a boom, since households fail to forecast long-run income and get over-indebted. Eventually, expectations adjust and a bust leading to a debt decline follows.

However, there are at least three dilemmas associated with the reliability of consumer confidence indicators. First, given the general disunity of economists on the question of economic agents' rationality, it remains an open question whether consumer surveys reflect a rational or irrational assessment of households' expectations of future economic developments. This remains a fruitful ground for future research. Second, the question of whether to focus on changes in levels or to consider changes between periods when analyzing consumer confidence indicators' values is not fully resolved. Third, it is not clear whether to focus on the actual values or the expectations of agents. In this spirit, Ludvigson (2004) assessed the relationship between consumer confidence indicators and the real economy. His results suggest that widely used consumer-based indexes contain some information on future aggregate consumption spending, but most of this information is already contained in other economic and financial indicators. According to his findings, "independent" additional information from consumer surveys only explains a relatively small proportion of changes in future consumer spending.

There are also several practical disadvantages with the data acquisition methods used to calculate consumer confidence indicators. First, the selected households may not be fully representative of the entire population, so there may be selection bias. Second, not all respondents will complete the survey in any given period. Third, consumer confidence indicators are based solely on the answers to the questions asked during the survey, and other aspects of consumer confidence are not captured. Fourth, there is a risk that respondents will not provide honest answers or give enough time to the questionnaire.

For the above-stated reasons, it is appropriate to look for alternative ways of expressing consumer confidence. One possibility is to create a composite index from information contained in commonly available macroeconomic indicators. Since some studies state that households commonly extrapolate recent and current macroeconomic conditions to the future (Bordalo et al. 2018), such a composite data-based indicator could serve as a useful approximation of households perceptions' of macroeconomic conditions.

\section{The Households' Macroeconomic Environment (HOME) Index}

Rich and extensive data are available to analyze the household sector in developed economies. Researchers and policymakers have access to both stock and flow data from a wide range of sources. However, interpreting the information contained in these variables may sometimes be difficult, because different variables may offer conflicting information about economic developments and overall market sentiment. Moreover, obtaining the required information can be complicated by the specific characteristics of the individual time series. Reliance on one indicator or very small set of indicators may thus be misleading when 
assessing conditions in the household sector (or any other sector of the economy). For this reason, many economists argue in favor of using a composite indicator which provides a broader view of the conditions in the selected sector. This approach is widely applied in analyses of, for example, the labor market (Chung et al. 2015; Willis and Hakkio 2014; Armstrong et al. 2016), monetary policy (Babecká-Kucharčuková et al. 2016; Frait and Malovaná 2017), and financial stress (Kremer et al. 2012).

The proposed HOME index uses the information contained in various economic aggregates, households' disposable income, labor market indicators, asset prices, interest rates, and external environment indicators. These variables form a comprehensive set of indicators reflecting the overall macroeconomic conditions faced by households. They come from a range of sources but are, in general, publicly available, so our proposed indicator is transparent and replicable by other researchers.

Table 1 provides an overview of the time series that enter the composite index, along with their definitions and sources. The selection of macroeconomic aggregates was motivated by previous studies on the predictive power of consumer confidence surveys (Carroll et al. 1994; Ludvigson 2004; Vanlaer et al. 2020). The decision to include financial aggregates was motivated by Leeper (1992) who finds that consumer attitudes are only weekly correlated with macroeconomic variables once financial indicators are included. We use a total of eleven variables, drawn mainly from the databases of the OECD, the Bank for International Settlements, and the ECB. ${ }^{1}$ Data for some countries were extracted directly from national statistical office or central bank databases. Table 4 offers summary statistics for the individual time series. The dataset can be divided into five logical blocks. Block I describes the development of the economic aggregates and the income of households. Gross domestic product and its growth is one of the most widely quoted indicators of economic performance. Still, it may not fully reflect households' economic conditions, especially in the short run. Therefore, it is supplemented by gross disposable income and gross savings to get a better picture of households' living standards. Block II captures the labor market situation. Compensation of employees and the number of employees provide a further indication of households' economic perceptions and may signal potential vulnerabilities. Block III shows the evolution of interest rates on consumer loans and mortgages. The lending rate directly influences households' access to credit. Since households perceive higher lending rates negatively, these variables enter the estimate at reciprocal value. Block IV shows asset price developments. These may influence consumer demand through the wealth effect (Cooper and Dynan 2016) and some psychological channels. Historically, real estate developments are a key indicator of households' financial vulnerability. Block $\mathrm{V}$ approximates the development of the external environment. For economies with a high level of openness, the evolution of exchange rates and the terms of trade could represent a significant force affecting domestic households' economic conditions.

Our original sample comprised 26 high-income OECD countries in Europe as defined by the World Bank. ${ }^{2}$ Due to data availability we ended up with a weakly unbalanced panel of 22 countries with a time span of 2002 Q1-2018 Q4. Table 2 provides the final list of countries together with an indication of whether the country is categorized as advanced, is

\footnotetext{
1 Note that only variables that cover a sufficiently wide range of countries over a sufficiently long time period are selected. As a result, a number of potentially useful indicators could not be included. Still, the databases consist of key proxy variables that are well established in the literature.

${ }^{2}$ See, for example, World Bank (2018a, b).
} 


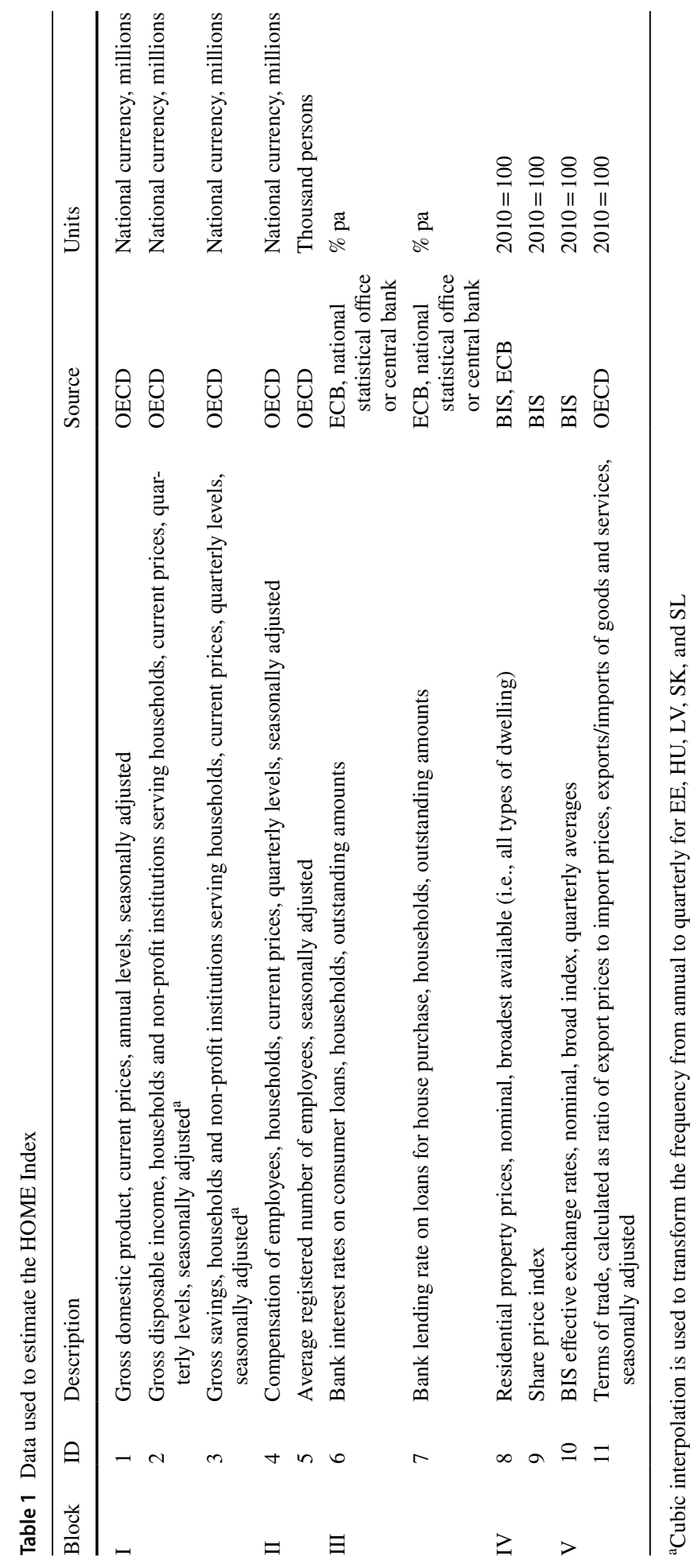


Table 2 Estimation sample

\begin{tabular}{|c|c|c|c|c|c|}
\hline & & OECD & IMF AE & $\mathrm{EU}$ & EA \\
\hline AT & Austria & $\mathrm{Y}$ & $\mathrm{Y}$ & $\mathrm{Y}$ & $\mathrm{Y}$ \\
\hline $\mathrm{BE}$ & Belgium & $\mathrm{Y}$ & $\mathrm{Y}$ & $\mathrm{Y}$ & $\mathrm{Y}$ \\
\hline $\mathrm{CZ}$ & Czechia & Y & 2009 & 2004 & $\mathrm{~N}$ \\
\hline $\mathrm{DE}$ & Germany & $\mathrm{Y}$ & $\mathrm{Y}$ & $\mathrm{Y}$ & $\mathrm{Y}$ \\
\hline DK & Denmark & $\mathrm{Y}$ & $\mathrm{Y}$ & $\mathrm{Y}$ & $\mathrm{N}$ \\
\hline $\mathrm{EE}$ & Estonia & 2010 & 2011 & 2004 & 2011 \\
\hline ES & Spain & $\mathrm{Y}$ & $\mathrm{Y}$ & $\mathrm{Y}$ & $\mathrm{Y}$ \\
\hline FI & Finland & Y & Y & Y & $\mathrm{Y}$ \\
\hline FR & France & $\mathrm{Y}$ & Y & $\mathrm{Y}$ & $\mathrm{Y}$ \\
\hline GR & Greece & Y & $\mathrm{Y}$ & Y & $\mathrm{Y}$ \\
\hline $\mathrm{HU}$ & Hungary & $\mathrm{N}$ & $\mathrm{N}$ & 2004 & $\mathrm{~N}$ \\
\hline IE & Ireland & $\mathrm{Y}$ & $\mathrm{Y}$ & Y & $\mathrm{Y}$ \\
\hline IT & Italy & $\mathrm{Y}$ & $\mathrm{Y}$ & $\mathrm{Y}$ & $\mathrm{Y}$ \\
\hline LV & Latvia & 2016 & 2014 & 2004 & 2014 \\
\hline NL & Netherlands & $\mathrm{Y}$ & $\mathrm{Y}$ & $\mathrm{Y}$ & $\mathrm{Y}$ \\
\hline NO & Norway & $\mathrm{Y}$ & $\mathrm{Y}$ & $\mathrm{N}$ & $\mathrm{N}$ \\
\hline PL & Poland & Y & $\mathrm{N}$ & 2004 & $\mathrm{~N}$ \\
\hline PT & Portugal & $\mathrm{Y}$ & Y & $\mathrm{Y}$ & $\mathrm{Y}$ \\
\hline SE & Sweden & $\mathrm{Y}$ & Y & $\mathrm{Y}$ & $\mathrm{N}$ \\
\hline SK & Slovakia & $\mathrm{Y}$ & 2009 & 2004 & 2009 \\
\hline SL & Slovenia & 2010 & 2007 & 2004 & 2007 \\
\hline UK & United Kingdom & $\mathrm{Y}$ & $\mathrm{Y}$ & $\mathrm{Y}$ & $\mathrm{Y}$ \\
\hline
\end{tabular}

$A E$ advanced economy as categorized by the IMF. Y/N indicates that the country does/does not belong to that category for the whole sample period (2001Q1-2018Q4); a specific year indicates the year of entry

a member of the European Union, and is part of the euro area. Overall, the sample can be considered relatively homogeneous and thus ready to use in a joint empirical framework.

\subsection{Factor Model Estimation Procedure}

There are several approaches that allow a large number of time series to be combined into a single composite index. In the case of the indicator presented in this paper, we use factor model estimation. Factor analysis allows for a large number of time series to be expressed as only a handful of components (factors). The aim of factor analysis is to identify the number of significant factors and to estimate the values of each of the factors for all the observable time series, i.e., to describe the time series using the estimated factors. In this respect, factor analysis can also be seen as a method for reducing the data scale.

We construct two state-space representations of a factor model. The first one is a fairly standard factor model which describes a direct linear relationship between the $N$-dimensional vector of observable variables and an $M$-dimensional random vector of originally unobservable factors $F=\left(F_{1}, \ldots, F_{m}\right)$. In this case, the observable variables enter the 
model in annual growth rates, except for lending rates, which are left in levels. ${ }^{3}$ The first specification can be written as follows:

$$
\begin{gathered}
X_{t}=\Lambda F_{t}+\varepsilon_{t} \sim N(0, R), \\
F_{t}=\sum_{i=1}^{p} A_{i} F_{t-1}+u_{i} \sim N(0, Q),
\end{gathered}
$$

where $\Lambda$ is a matrix of factor loadings, $A_{i}$ is a matrix of autoregressive coefficients for $p$ lags, and $\varepsilon_{t}, u_{t}$ are i.i.d. Gaussian error terms.

The second factor model specification takes a step further and introduces an additional two equations decomposing the observable variables into a trend and cycle component. The factors are then related to the unobserved cycle (gap) component of the observable variables. By doing so, we keep the information about the level of a given variable, which, in some cases, might be of great importance. Let us elaborate using a simple example from the labor market. Picture a situation in which the labor market grows for several years in a row to the point where it becomes exhausted by insufficient supply. At this point, the number of employees might not change on a year-to-year basis, but the country's labor market would still be exhausted by significant upward pressures on wages. Such a situation would be difficult to capture by year-to-year dynamics. The second specification can be written as follows:

$$
\begin{gathered}
X_{t}=\hat{X}_{t}+X_{t}^{*}, \\
\hat{X}_{t}=\Lambda F_{t}+\varepsilon_{t} \sim N(0, R), \\
F_{t}=\sum_{i=1}^{p} A_{i} F_{t-1}+u_{i} \sim N(0, Q), \\
X_{t}^{*}=X_{t-1}^{*}+\eta_{t} \sim N(0, H),
\end{gathered}
$$

which can be rewritten in state-space form as follows:

$$
\begin{gathered}
X_{t}=B Z_{t}, \\
Z_{t}=C Z_{t-1}+\Pi_{t},
\end{gathered}
$$

where $Z_{t}=\left[\hat{X}_{t}, X_{t}^{*}, F_{t+1}\right], B=\left[I_{N x N}, I_{N x N}, 0_{N x M}\right]$,

$$
C=\left[\begin{array}{cc}
0_{N x N} & 0_{N x N} \Lambda \\
0_{N x N} & I_{N x N} 0_{N x M} \\
0_{M x N} & 0_{M x N} A
\end{array}\right] \text { and } \Pi_{t} \sim N\left(0,\left[\begin{array}{ccc}
R & 0_{N x N} & 0_{N x M} \\
0_{N x N} & I_{N x N} & 0_{N x M} \\
0_{M x N} & 0_{M x N} & Q
\end{array}\right]\right) \text {. }
$$

The variables decomposed into trend and cycle components within the model are gross domestic product, gross disposable income, gross savings, compensation of employees,

3 All variables are standardized using their long-run mean and standard deviation. 

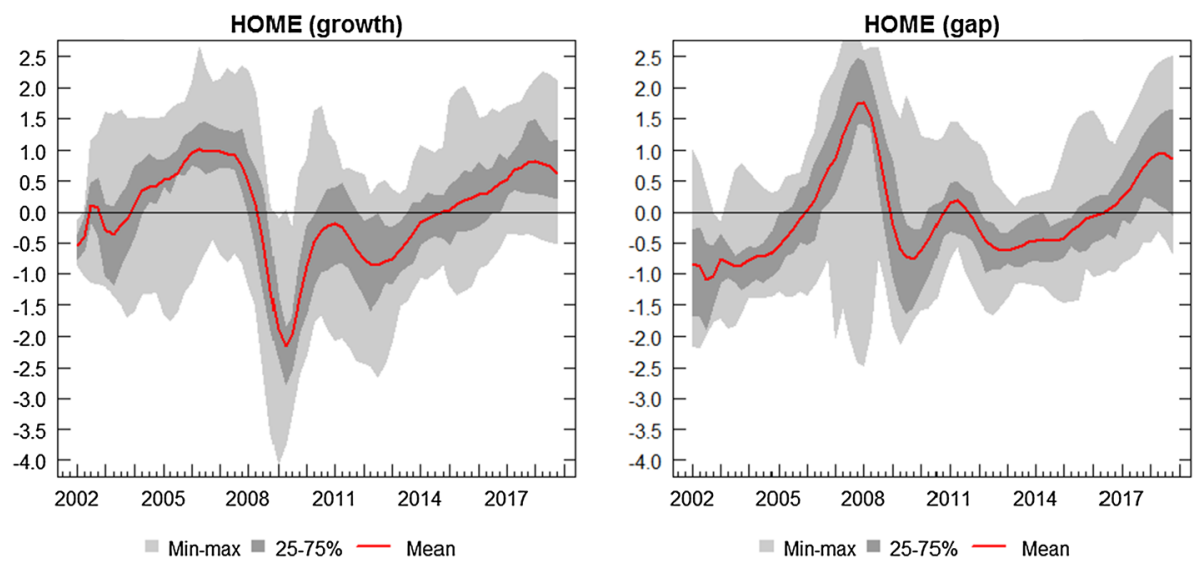

Fig. 1 The HOME Index for selected countries. Note The index is standardized using its long-run mean and standard deviation; the vertical axis shows the standard deviations. The HOME index values for individual countries are depicted in Fig. 7 in Appendix 1

number of employees, and property prices. Except for lending rates, the remaining variables (the share price index, effective exchange rates, and terms of trade) are in annual growth rates. ${ }^{4}$

Both factor models are estimated using the Kalman filter. ${ }^{5}$ The optimal number of factors to estimate is based on parallel analysis ${ }^{6}$ and an assessment of the percentage of the variance explained by the factors estimated ${ }^{7}$ (see Table 5 in the Appendix 1). The optimal number of lags is set based on the Schwarz information criterion. Based on the statistical tests, our baseline model specification is a factor model with three factors and one lag. ${ }^{8}$ The final indexes are robust to the inclusion of additional factors, as the variance explained by three factors is already high. The index is also relatively robust to the exclusion of the third factor, as most of the variance is explained by the first two factors in most cases.

The paths of the resulting growth and gap versions of the HOME index are shown in Fig. 1. The synthetic indicator is constructed for each country in the sample as a weighted average of the individual factors, with the weights corresponding to the percentage of the total data variability explained by the factors. The resulting index is then standardized. ${ }^{9}$

\footnotetext{
${ }^{4}$ In this case again, all variables are standardized using their long-run mean and standard deviation.

5 The initial conditions are set as follows. Firstly, we estimate $\Lambda$ and F by applying principal component analysis to the covariance matrix of $\mathrm{X}$ (the first factor model) or $\widehat{X}$ (the second factor model); $\hat{X}$ is estimated using a simple Hodrick-Prescott filter with lambda equal to 1600 . Secondly, we obtain A and Q by estimating a vector autoregression (VAR) model on $\widehat{F} ; \mathrm{R}$ and $\mathrm{H}$ are set to be identity matrices.

6 The results of the parallel analysis are not reported, but are available upon request.

7 We set the threshold level of the variance explained to at least $70 \%$. This condition is satisfied by models with three estimated factors for all sample countries. Hair et al. (2012) state that the acceptable variance explained in the social sciences for a construct to be valid is $60 \%$. By extracting information from 803 substantive factor analyses, Peterson (2000) shows that the average percentage of the variance accounted for is about $60 \%$.

${ }^{8}$ We do not record any missing data in our sample. Since we work with aggregate time series for the entire economy, we do not winsorize the data.

9 The index is standardized using the z-score formula. The z-score is calculated for each country as the difference between the actual value of the HOME index and its long-run average divided by its long-run standard deviation; it expresses the distance of the index in a given year from its historical mean expressed in
} 
This means that for each estimate the long-term mean is zero. Positive values signal favorable macroeconomic conditions (above-average conditions) and negative values unfavorable macroeconomic conditions (below-average conditions). These are then reflected in households' optimism or pessimism about the future economic outlook. The more distant the indicator is from zero, the more optimistic/pessimistic the outlook is. As is apparent from the graph, the HOME index describes households' evolving macroeconomic conditions across countries fairly well. At the beginning of the period under review, macroeconomic conditions were affected by the echoes of the Dot-com bubble burst and the resulting decline in aggregate demand. During the Great Moderation that followed, we see a gradual increase in the HOME index values, reflecting a general improvement in households' conditions and perception of their economic situation. In this context, long-lasting accommodative monetary policy was found to be one of the significant factors in the accumulation of imbalances that led to the GFC outbreak (Obstfeld and Rogoff 2009; White 2009). In particular, Maddaloni and Peydró (2013) and Jiménez et al. (2014) explain how low shortterm rates helped to boost credit and macroeconomic dynamics through their contribution to the softening of lending standards during the pre-GFC times. The favorable macroeconomic conditions were shattered with the onset of the GFC in 2008-2009, and the negative mood persisted essentially until the end of 2014. Since 2015, optimism has prevailed in the HOME index, which reached the pre-GFC levels at the end of 2017. This rise in optimism has been fed mostly by favorable macroeconomic developments, but also by a long period of historically low interest rates.

\subsection{Comparison of the HOME Index and the OECD Consumer Confidence Index}

Despite the widespread use of surveys of consumer confidence in various economic applications, the mechanisms by which households' attitudes influence the real economy are rarely discussed. One may thus ask whether consumer confidence indicators contain meaningful and independent information about economic developments, or if they just repackage the information already contained in basic economic indicators. This issue was addressed in Ludvigson (2004) and more recently in Barnes and Olivei (2017). There is a consensus that the role of consumer sentiment in consumption is typically small from an economic standpoint, even if often statistically significant. One might argue that consumer confidence indicators possess some time advantage over macroeconomic indicators, which are often revised. The consumer confidence indicators can thus be considered better realtime predictors.

In this section, we analyse the mutual relationship between the consumer confidence index (CCI) published by the OECD and the newly developed HOME index. The CCI is calculated as a simple average of answers to questions regarding respondents' past and future (expected) financial situation, expected economic situation, and unemployment expectations. The CCI is thus constructed as forward-looking, since the questions dealing with expectations over the next 12 months are strongly favored (three to one).

Footnote 9 (continued)

terms of the number of standard deviations. This allows its relative position in relation to the historical data to be assessed. As the number is based on the assumption of a normal distribution, $68 \%$ of the outcomes are going to be no more than one standard deviation unit away from the mean, and $95 \%$ of the outcomes are going to be no more than two standard deviation units away from the mean. 
When looking at the evolution of the two HOME index and the CCI, we spot a significant correlation between the two types of index for a majority of countries in the sample (see Figs. 7 and 8 and Table 6). The correlation is generally higher when both indexes are considered at time $t$, but one must keep in mind that the CCI is meant to be forward-looking (four quarters ahead). This explains why the correlation remains strong even when we consider the lagged HOME index $(t+4)$ and the CCI $(t)$. This suggests that households' optimistic/pessimistic expectations captured in the CCI are tightly linked to the current or very recent development of macroeconomic conditions. This is not that surprising since most households should be aware of recent changes in their own economic situation.

The interesting question is whether consumers tend to simply extrapolate past information into the future or they are adaptive in their behaviour, learning from the past and adjusting their future expectations accordingly. To answer this question, we regress the CCI on the contemporaneous $(t)$, lead, and lagged values of the HOME index. We further check whether the simple bivariate statistics can survive increasingly demanding statistical tests.

The independent variables include up to four lags $(t-4)$ and four leads $(t+4)$ of the HOME index. For each specification, we present the parameter estimate and the adjusted R-squared statistic to see how well the HOME index can explain the formation of CCI values. Results are summarized in Table 3.

The results point to four main findings related to the growth version of the HOME index. First, changes to the HOME index are found to explain a large portion of changes to the CCI. We report positive parameter estimates at all lags and leads of the HOME index showing that improving macroeconomic conditions are associated with increases of consumer confidence. The estimates are reported to be statistically significant at a $1 \%$ level, leaving very little probability that they were generated by chance.

Second, the HOME index is estimated to have the highest explanatory power for the CCI when considering the contemporaneous relationship $(t)$ and the HOME index up to two leads $(t+2)$. For instance, a 1 percentage point increase in the HOME index at time $t$ translates into 0.62 increase in the CCI while the same increase of the HOME index lagged by four quarters $(t-4)$ leads to more than two-times smaller increase in the CCI. This shows that consumers' expectations about their future economic prospects load more on current or very recent values of economic variables.

Third, the model's explanatory power, as measured by the adj. R-squared, decreases with the increasing lag of the HOME index. This shows that households' expectations are not all that adaptive. In another words, households value current economic information more than past economic information which quickly loses value. This echoes the fact that the current HOME index values at time $t$ explain a significantly larger portion of the CCI than the lagged values (43\% vs $19 \%$ on average).

Fourth, increasing the lead of the HOME index modestly increases the explanatory power for the CCI values. At time $t+2$, the HOME index explains over $50 \%$ of the CCI variation. While bearing in mind that the CCI is meant to be forward-looking (1 year into the future), this shows that households tend to extrapolate expectations of current economic conditions into the future.

Overall, our estimates show that consumers' answers to the survey questions that are used to calculate the CCI are largely based on current or very recent macroeconomic fundamentals. Moreover, consumers tend to pin down their beliefs about the future based on their current economic situation which is then gradually extrapolated into the future. Still, having found that the macroeconomic fundamentals (measured by the HOME index) explain about $50 \%$ of the consumer confidence variation (the CCI), there is still space left 
Table 3 Relationship between the HOME Index and the CCI at different lags and leads

\begin{tabular}{|c|c|c|c|}
\hline $\begin{array}{l}\text { Dependent variable: } \\
\text { Consumer Confidence } \\
\text { Index }(\mathrm{CCI})\end{array}$ & Parameter & Adj. $R^{2}$ & No. of obs \\
\hline \multicolumn{4}{|c|}{ HOME index (growth version) } \\
\hline HOME index $(\mathrm{t}+4)$ & $\begin{array}{l}0.528 * * * \\
(0.022)\end{array}$ & 0.32 & 1.173 \\
\hline HOME index $(\mathrm{t}+3)$ & $\begin{array}{l}0.613 * * * \\
(0.02)\end{array}$ & 0.43 & 1.194 \\
\hline HOME index $(\mathrm{t}+2)$ & $\begin{array}{l}0.660 * * * \\
(0.019)\end{array}$ & 0.50 & 1.215 \\
\hline HOME index $(t+1)$ & $\begin{array}{l}0.662 * * * \\
(0.019)\end{array}$ & 0.50 & 1.236 \\
\hline HOME index (t) & $\begin{array}{l}0.618 * * * \\
(0.02)\end{array}$ & 0.43 & 1.257 \\
\hline HOME index $(\mathrm{t}-1)$ & $\begin{array}{l}0.541 * * * \\
(0.022)\end{array}$ & 0.33 & 1.236 \\
\hline HOME index $(\mathrm{t}-2)$ & $\begin{array}{l}0.448 * * * \\
(0.024)\end{array}$ & 0.22 & 1.215 \\
\hline HOME index $(\mathrm{t}-3)$ & $\begin{array}{l}0.354 * * * \\
(0.025)\end{array}$ & 0.13 & 1.194 \\
\hline HOME index $(\mathrm{t}-4)$ & $\begin{array}{l}0.273 * * * \\
(0.026)\end{array}$ & 0.07 & 1.173 \\
\hline \multicolumn{4}{|c|}{ HOME index (gap version) } \\
\hline HOME index $(\mathrm{t}+4)$ & $\begin{array}{l}0.569 * * * \\
(0.024)\end{array}$ & 0.32 & 1.189 \\
\hline HOME index $(t+3)$ & $\begin{array}{l}0.539 * * * \\
(0.024)\end{array}$ & 0.28 & 1.210 \\
\hline HOME index $(t+2)$ & $\begin{array}{l}0.461 * * * \\
(0.026)\end{array}$ & 0.20 & 1.231 \\
\hline HOME index $(\mathrm{t}+1)$ & $\begin{array}{l}0.341 * * * \\
(0.027)\end{array}$ & 0.10 & 1.252 \\
\hline HOME index (t) & $\begin{array}{l}0.196 * * * \\
(0.028)\end{array}$ & 0.02 & 1.273 \\
\hline HOME index $(\mathrm{t}-1)$ & $\begin{array}{l}0.042 \\
(0.029)\end{array}$ & 0.02 & 1.252 \\
\hline HOME index $(\mathrm{t}-2)$ & $\begin{array}{l}-0.105^{* * * *} \\
(0.029)\end{array}$ & 0.01 & 1.231 \\
\hline HOME index $(\mathrm{t}-3)$ & $\begin{array}{l}-0.226^{* * * *} \\
(0.029)\end{array}$ & 0.03 & 1.210 \\
\hline HOME index $(t-4)$ & $\begin{array}{l}-0.307 * * * \\
(0.029)\end{array}$ & 0.07 & 1.189 \\
\hline
\end{tabular}

This table presents estimates based on panel data regression with country fixed effects for 21 countries between 2002 Q1 and 2018 Q4 (see Fig. 7 in Appendix 1 for the individual time series). The specification is as follows: $C C I_{i, t}=\alpha H O M E_{i, t-p}+v_{i}+\varepsilon_{i, t}$, where $p=-4,-3, \ldots, 4$; the panel is weakly unbalanced. Standard errors are reported in parentheses. $* * *, * *$, and $*$ denote the $1 \%, 5 \%$, and $10 \%$ significance levels 

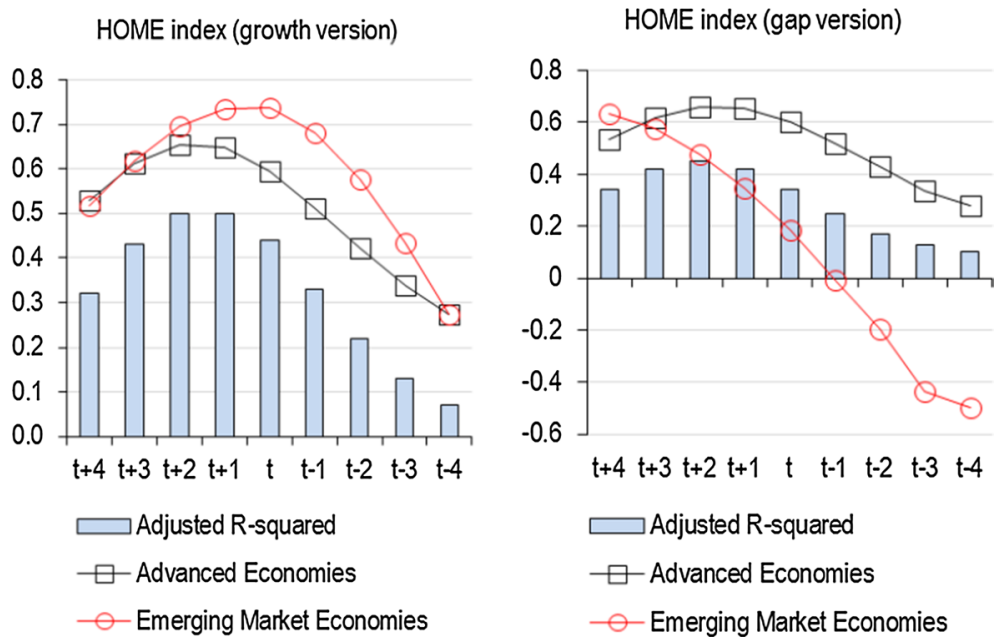

Fig. 2 Relationship between the HOME Index and the CCI at Different Lags and Leads-Advanced Economies versus Emerging Market Economies. Note The figure sums up the estimates based on panel data regression with fixed effects

for the non-fundamental (irrational) determinants which may be captured by the HOME index only to a limited extent.

The gap version of the HOME index has much lower explanatory power than the growth version at its current value and at lagged values. This significantly limits the ability of this version to be used as a leading indicator of households' macroeconomic conditions. However, the gap version of the HOME index may still serve well as a backward-looking indicator, because it is able to capture the conditions ex post. Its main value added is that it takes into consideration long-run trends and the deviation from these trends. Nevertheless, this feature possibly also explains why the index is not forward-looking and reliable at the end of the sample period. ${ }^{10}$

Having established that consumers favor current information over the past ones and tend to extrapolate them into the future, we check whether the estimates differ between advanced and emerging market economies. In our sample, we mark the following countries as emerging: the Czech Republic, Estonia, Hungary, Latvia, Poland, Slovakia, and Slovenia (see Table 2 for a full sample overview). Figure 2 shows the evolution of the model parameters while differentiating between the sample of advanced and emerging market economies. This empirical exercise is meant to reflect the fact that emerging markets have been widely understood to have higher stock price volatility, weaker market efficiency, lower liquidity, and higher macroeconomic and policy uncertainty. "Animal spirits" might thus influence the real economy more in emerging than in advanced economies which would be materialized via low explanatory power for the HOME index. In another words, the formation of consumer confidence might not be that strongly linked to macroeconomic fundamentals in case of emerging markets.

\footnotetext{
${ }^{10}$ Any filtration technique trying to separate the trend from the cyclical component suffers to some extent from end-point bias.
} 
Interestingly, our estimates argue against a significant role of sentiment (as determined by consumer confidence) and in favor of extrapolative expectations in both advanced and emerging market economies. The parameter values and the adjusted R-squared are the highest when considering current values of the growth version of the HOME index at time $t$. If anything, we find the parameter estimates to be even more pronounced in case of emerging markets pointing to a prominent role for macroeconomic fundamentals in explaining the formation of consumer confidence. The negative coefficient estimates of the gap version of the HOME index at higher lags are driven mainly by emerging market economies. This may point to the difficulty of separating trend and gap components in economies whose convergence is not finished yet and whose data series are usually shorter.

\section{Case Study Analysis: The HOME Index and Credit Dynamics in the Czech Republic}

This section turns to a case study of the Czech Republic to offer some deeper understanding of, and economic intuition for, the values of the HOME index and its relationship with households' credit dynamics. Credit dynamics currently stands in the center of focus of policymakers worldwide since owing to the continuous process of financialization the credit dynamics has become a prominent determinant of the macroeconomic dynamics (van der Zwan 2014). The fluctuations in household credit and related asset prices happen to be an important source of economic instability. The impacts of such swings during and after the GFC turned to be particularly costly (Jorda et al. 2011).

After a period of transformation in the early 1990s, the Czech Republic went through a deep banking crisis during 1996-2000. Since then, the economy has gone through a full business and financial cycle. It was hit by the GFC, which resulted in a short recession and a partial loss of confidence. Since the Czech Republic is a small open economy, the slowdown in economic growth was caused predominantly by economic spillovers from its trading partners, while the Czech financial sector remained sound throughout the recession. Given the structure of the economy, which is largely export-oriented, it would be interesting to see (among other things) to what extent the domestic macroeconomic conditions, as captured by the HOME index, are affected by external developments. Because the growth version of the HOME index possesses more favorable forward-looking features than the gap version, we focus solely on the growth version of the index.

Before we delve into an empirical investigation, we check for the robustness of the estimated HOME index against two potential issues. First, we check whether the resulting index is sensitive to the number of estimated factors. Second, we estimate the HOME index in real time and analyse its real-time revision properties. Third, we check against the choice of input variables.

The robustness tests are summarized in the Appendix 3. Figure 9 (left-hand graph) shows that the resulting index is largely invariant to the number of estimated factors. We have estimated the index using from two to six factors which yielded quantitatively similar estimates. Figure 9 (right-hand graph) shows the results of a set of historical simulations where the index is estimated using shortened sample periods. This is meant to check whether the resulting index is sensitive to revisions of the input time series. The estimates suggest that the HOME index is largely robust to sample perturbations. Figure 10 shows results of a simulation exercise in which the index was estimated multiple times, each time with one variable excluded from the input data set. This approach is very similar to the 


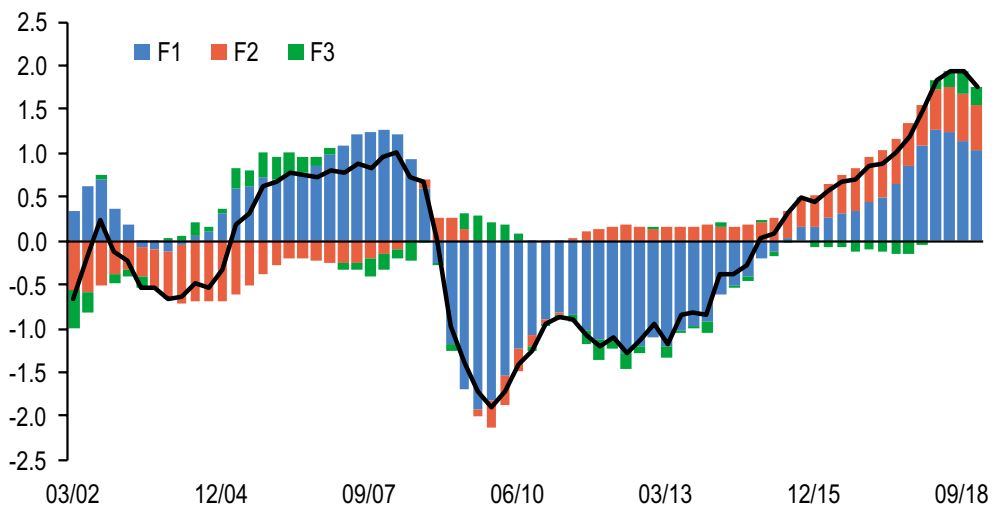

Fig. 3 HOME Index Decomposition for the Czech Republic. Note The vertical axis reflects the standard deviation. The graph depicts the growth version of the HOME index

more formal bootstrapping proposed by Gospodinov and $\mathrm{Ng}$ (2013). All the estimates are similar, suggesting that the HOME index is not being driven by any single input variable.

Figure 3 shows the contributions of the individual estimated factors to the aggregate HOME index. ${ }^{11}$ From that and a visual inspection of the raw time series (see Fig. 11 in Appendix 3), we can draw conclusions about their possible interpretation. To lay some statistical support, we also check for correlations of sub-groups of variables with the estimated factors. It seems that Factor 1 captures the evolution of major macroeconomic aggregates and asset prices. In the context of the period analyzed, it captures the typical situation in a period of prosperity where GDP, employment, wages-and, with them, disposable income-are rising. The increasing income and wealth lead to growth in property prices and stock prices. Factor 1 strongly follows the development of the economy and contributes significantly to the growth in the overall index. Factor 2 captures the development of lending rates and the echoes from the domestic labor market in the form of employment growth. As such, it has been contributing to growth in the overall index since the second half of 2011, when interest rates reached all-time lows compressed to all-time lows. It has been gaining momentum since 2013, and its contribution remains high until the end of the period analyzed. Factor 3 loads on households' savings, disposable income, and share prices, but given the structure of the financial system, which is largely bank-based, and the relative conservativeness of Czech households, its contribution to the overall index is minor.

To explore the relationship between the HOME index and credit dynamics, we resort to a simple forecasting exercise. Specifically, we use the method of dynamic model averaging (DMA), originally introduced for engineering applications in Raftery et al. (2010). Koop and Korobilis $(2011,2012)$ were among the first to implement DMA in an economic application to forecast US and UK inflation. DMA consists of many time-varying coefficient regression models formed from all possible combinations of the predictors available to the practitioner. It allows the forecasting model to change over time while allowing the coefficients in each model to evolve over time. It can be seen as an extension of the more

11 Results of robustness and sensitivity tests of the HOME index estimation can be found in Appendix D. 
Growth in new loans for house purchase

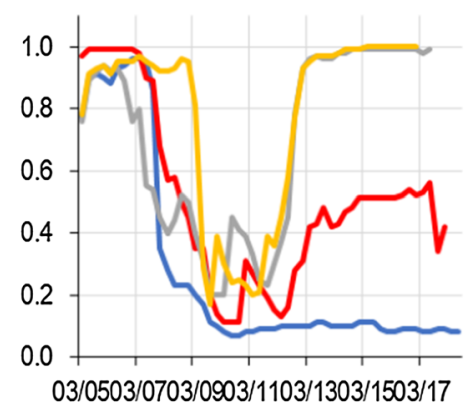

$-\mathrm{h}=2-\mathrm{h}=4-\mathrm{h}=6-\mathrm{h}=8$
Growth in new loans for consumption
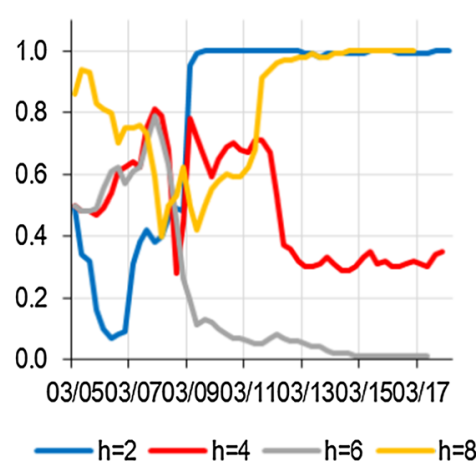

Fig. 4 Posterior inclusion probabilities for credit models containing the HOME Index. Note The time axis corresponds to the forecasted variable. The raw credit data in levels are transformed before estimation using 12-month moving averages to overcome their seasonality patterns. The data enter the estimation in annual growth rates

traditional Bayesian model averaging (BMA) into a time-varying framework. Our baseline prediction model takes on the following form:

$$
\begin{gathered}
y_{t}=z_{t}^{(k)} \xi_{t}^{(k)}+\varepsilon_{t}^{(k)}, \\
\xi_{t+1}^{(k)}=\xi_{t}^{(k)}+\eta_{t}^{(k)},
\end{gathered}
$$

where $y_{t}$ is the dependent variable to be forecasted. In our application, $y_{t}$ is the annual growth rate of new loans to households. We differentiate between types of loans, i.e., we consider two separate models for consumer loans and mortgages. Additionally, we consider consumer spending as a forecasted variable. $z_{t}^{(k)}$ for $k=1,2, \ldots, K$ denotes a specific predictor set. We consider the HOME index and past values of the predicted variable as potential predictors (up to lag four). In the end, we are merely interested in finding out if the inclusion of the HOME index yields any additional gains over the information content in the past values of the forecasted variables. $\varepsilon_{t}^{(k)}, \eta_{t}^{(k)}$ are error terms that are $N\left(0, V_{t}^{(k)}\right)$ and $N\left(0, W_{t}^{(k)}\right)$ respectively. Details on the estimation procedure are available in Appendix D.

The main outcome from DMA is a posterior inclusion probability (PIP). The PIP refers to the sum of the probabilities $\left(\xi_{t \mid t-1, k}\right)$ that a given predictor will be included among the set of viable predictors in the forecasting model $k(k=1,2, \ldots, K)$ of DMA at time $t$. In other words, the higher is the value of PIP, the more forecasting weight is assigned to the given predictor and the higher forecasting power that predictor has.

Figure 4 shows the estimated PIP values and their development across time for models with different forecasted horizons. To reduce visual cluster, we only report PIP values for models containing the HOME index as a predictor and omit the rest. From visual exploration, it is apparent that there are some differences between the models predicting growth of consumer loans and mortgages. Specifically, the HOME index is found to be a dominant predictor of consumer loan growth at short horizons (up to three quarters) and of mortgage growth at long horizons (from six quarters up). This shows that households generally need 
Growth in households' expenditure on consumption

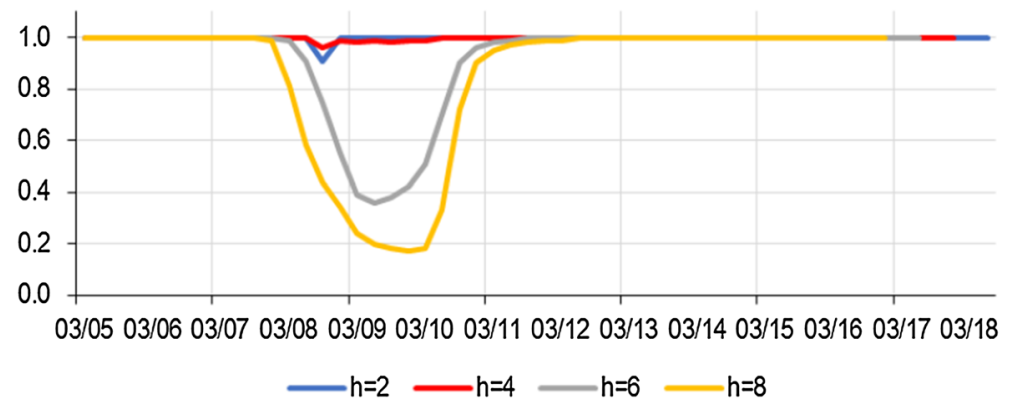

Fig. 5 Posterior inclusion probabilities for consumption models containing the HOME Index. Note The time axis corresponds to the forecasted variable. The data enter the estimation in annual growth rates

a longer period of good macroeconomic conditions to decide to take on a mortgage than they do in the case of a consumer loan.

Motivated by the large body of literature that discusses the role of consumers' attitudes in their consumption behavior, we check the predictive power of our proposed index in relation to the growth in the consumption expenditure of households. This exercise mimics the previous one, i.e., lagged values of consumption growth are the competitor of the HOME index. As is apparent from the PIP values (Fig. 5), models containing the HOME index convincingly dominate their competitors over the entire sample. The PIP decreases sometime around the GFC, which means the HOME index performed worse during this period than the lagged values of consumer expenditure. This is not surprising given the growing body of literature that discusses the role of non-fundamental factors in explaining households' consumption behavior (Dees and Brinca 2013; Bailey et al. 2017).

\section{Conclusion}

In the paper, we construct a novel index of households' macroeconomic environment (the HOME index) based on the observations from 22 high-income OECD countries in Europe at quarterly frequency between 2002 and 2018. The proposed index combines the information contained in various economic aggregates, households' disposable income, labor market indicators, asset prices, interest rates, and external environment indicators. The variables come from a range of sources but are, in general, publicly available, so our proposed index is transparent and replicable by other researchers. We focus on short- to mediumterm conjunctural developments while leaving aside structural factors that affect the households' perceptions mainly in the long-run.

We demonstrate that the evolution of the HOME index is in line with the broad characteristics of the business and financial cycles. The index is robust to variable and estimator choice and to the estimation period. Overall, the index is an improvement over the traditional measures of households' economic conditions. As such, it may be used in various empirical exercises analyzing or controlling for the impact of households' macroeconomic conditions.

We discuss the favorable statistical characteristics of the proposed index in relation to widely employed consumer confidence indexes. In a simple empirical framework, we 
compare the outcomes of the HOME index and the popular consumer confidence index (CCI) published by the OECD. We report a strong correlation when considering the contemporaneous relationship between the two indexes. Having established a strong empirical link between the CCI and current as well as past values of the HOME index, we show that the consumer confidence is largely based on the development of macroeconomic fundamentals. Further, we show that the CCI loads on current or very recent macroeconomic data and thus uses the same historical information subject to revisions. These finding serves as an empirical manifestation of being in line with of the concept of extrapolative expectations, arguing that expectations are formed by extrapolating recent trends and can thus become temporarily self-fulfilling (Benhabib and Speigel 2019). For example, a long period of "good times" may give the illusion that these times will continue into the future and that the inevitable turn in the cycle will not occur or will occur further in the future or to a lesser extent.

The HOME index has naturally limited capacity to predict major swings in households' behavior resulting from disruptive events such as COVID-19 pandemics that lead to sharp swings in spending, income and wealth (Coibion et al. 2020). However, by capturing changes in broad spectrum of macroeconomic and financial variables, its use may be helpful in estimating the changes in credit development once the pandemic begins to wane.

As an example of potential application, we use the index in a single-country case study. Specifically, we test its ability to predict the evolution of new loans extended to households in the Czech Republic. In the process, we differentiate between consumer loans and mortgages, since they represent different decision-making processes of households. We find that the predictive performance of the HOME index is high for consumer loans at short horizons. In the case of mortgages, we report quite the opposite. At short horizons, the HOME index performs equally as well (or badly) as a simple autoregressive process. However, at longer horizons, we find the HOME index to be a dominant predictor of growth in new mortgages, suggesting a need for a longer period of good macroeconomic conditions for households to take on a mortgage.

In a potential extension of our work, one might follow the rich discussion on the role of non-fundamental (rational or irrational) drivers of economic development which may influence the decision of households regarding their indebtedness. Extrapolative expectations as such cannot be considered fully rational and can encourage households to become over-indebted. The HOME index captures irrational households' beliefs only to limited extent through the developments of through asset prices that often show up strong cyclical swings of not fully fundamental nature. Thus, the deviations of consumer attitudes from fundamental drivers of credit dynamics may reflect the true sentiment and the uncertainty surrounding the economic environment.

\section{Appendix 1: Factor model}

See Tables 4, 5 and 6 and Figs. 6, 7 and 8. 
Table 4 Summary statistics of variables entering the factor model

\begin{tabular}{|c|c|c|c|c|c|c|c|c|c|c|c|c|}
\hline \multirow[t]{3}{*}{ ID } & \multicolumn{2}{|l|}{1} & \multicolumn{2}{|l|}{2} & \multicolumn{2}{|l|}{3} & \multicolumn{2}{|l|}{4} & \multicolumn{2}{|l|}{5} & \multicolumn{2}{|l|}{6} \\
\hline & \multicolumn{2}{|c|}{$\begin{array}{l}\text { GDP (YoY } \\
\text { growth, \%) }\end{array}$} & \multicolumn{2}{|c|}{$\begin{array}{l}\text { GDI (YoY } \\
\text { growth, \%) }\end{array}$} & \multicolumn{2}{|c|}{$\begin{array}{l}\text { GS (YoY growth, } \\
\%)\end{array}$} & \multicolumn{2}{|c|}{$\begin{array}{l}\text { Compensation } \\
\text { (YoY growth, } \\
\%)\end{array}$} & \multicolumn{2}{|c|}{$\begin{array}{l}\text { Employment } \\
\text { (YoY growth, } \\
\% \text { ) }\end{array}$} & \multicolumn{2}{|c|}{$\begin{array}{l}\text { Lending rate } \\
\text { cons. loans } \\
\text { (\% pa) }\end{array}$} \\
\hline & Mean & SD & Mean & SD & Mean & SD & Mean & SD & Mean & SD & Mean & SD \\
\hline AT & 3.4 & 2.0 & 3.1 & 2.2 & 3.0 & 12.0 & 3.5 & 1.3 & 0.9 & 0.7 & 4.7 & 1.3 \\
\hline $\mathrm{BE}$ & 3.3 & 1.9 & 2.9 & 1.9 & 0.6 & 8.7 & 3.0 & 1.6 & 0.9 & 0.7 & 5.7 & 1.1 \\
\hline CZ & 4.4 & 3.3 & 4.0 & 2.5 & 4.7 & 14.5 & 5.1 & 3.5 & 0.7 & 1.1 & 13.6 & 1.2 \\
\hline DE & 2.7 & 2.3 & 2.3 & 1.2 & 3.3 & 3.1 & 2.8 & 1.7 & 0.8 & 0.7 & 5.8 & 0.9 \\
\hline DK & 2.9 & 2.5 & 3.4 & 3.7 & 28.3 & 90.7 & 3.1 & 2.0 & 0.3 & 1.5 & 6.1 & 1.4 \\
\hline EE & 7.0 & 8.9 & 7.2 & 7.2 & -53.4 & 485.5 & 7.9 & 9.4 & 0.7 & 4.2 & 8.5 & 1.6 \\
\hline ES & 3.1 & 3.9 & 2.8 & 3.5 & 4.5 & 34.7 & 2.7 & 4.6 & 0.8 & 3.2 & 5.9 & 0.4 \\
\hline FI & 2.9 & 3.2 & 3.4 & 2.2 & 11.4 & 48.0 & 2.9 & 2.3 & 0.7 & 1.5 & 4.2 & 1.1 \\
\hline FR & 2.5 & 1.9 & 2.4 & 1.7 & 2.2 & 6.5 & 2.6 & 1.1 & 0.5 & 0.6 & 6.0 & 1.2 \\
\hline GR & 1.1 & 5.8 & 0.7 & 7.1 & -12.0 & 364.7 & 1.6 & 7.6 & -0.2 & 2.9 & 10.7 & 0.9 \\
\hline $\mathrm{HU}$ & 5.2 & 3.5 & 4.6 & 2.5 & 7.5 & 16.6 & 4.8 & 3.5 & 1.0 & 2.0 & 7.1 & 0.9 \\
\hline IE & 6.0 & 9.4 & 3.7 & 5.1 & 12.3 & 33.5 & 4.1 & 5.9 & 1.5 & 3.5 & 6.5 & 1.0 \\
\hline IT & 1.7 & 2.3 & 1.5 & 2.1 & -0.7 & 10.1 & 2.2 & 2.2 & 0.3 & 1.2 & 5.9 & 0.9 \\
\hline LV & 5.4 & 12.6 & 5.3 & 10.8 & -83.3 & 939.8 & 7.1 & 15.9 & -0.9 & 5.2 & 8.6 & 2.5 \\
\hline NL & 2.8 & 2.4 & 2.3 & 1.9 & 5.6 & 17.9 & 2.5 & 1.9 & 0.6 & 1.3 & 5.5 & 0.8 \\
\hline NO & 5.4 & 5.4 & 5.1 & 3.1 & 9.5 & 28.5 & 5.4 & 2.8 & 1.2 & 1.4 & 5.8 & 1.8 \\
\hline PL & 6.0 & 2.7 & 5.3 & 2.4 & 15.4 & 68.7 & 6.6 & 3.3 & 1.2 & 1.8 & 11.7 & 2.6 \\
\hline PT & 2.3 & 2.9 & 2.1 & 2.9 & 3.2 & 39.5 & 1.8 & 3.5 & -0.2 & 2.1 & 8.0 & 0.6 \\
\hline SE & 4.0 & 2.7 & 4.5 & 1.5 & 12.7 & 16.4 & 4.4 & 1.9 & 1.2 & 1.2 & 6.1 & 1.1 \\
\hline SK & 4.6 & 4.8 & 4.5 & 3.4 & 6.9 & 14.2 & 5.7 & 3.5 & 1.2 & 2.1 & 9.4 & 2.1 \\
\hline SL & 2.5 & 3.9 & 2.6 & 3.1 & 1.0 & 12.6 & 2.7 & 4.1 & 0.6 & 2.0 & 5.8 & 0.9 \\
\hline UK & 3.8 & 2.0 & 3.7 & 1.5 & 4.0 & 21.9 & 3.8 & 2.4 & 0.9 & 0.9 & 8.0 & 1.1 \\
\hline \multirow[t]{3}{*}{ ID } & \multicolumn{2}{|l|}{7} & \multicolumn{3}{|l|}{8} & \multicolumn{2}{|l|}{9} & \multicolumn{2}{|l|}{10} & \multicolumn{3}{|c|}{11} \\
\hline & \multicolumn{2}{|c|}{$\begin{array}{l}\text { Lending rate } \\
\text { housing loans } \\
\text { (\% pa) }\end{array}$} & \multicolumn{3}{|c|}{$\begin{array}{l}\text { Property prices } \\
\text { (YoY growth, \%) }\end{array}$} & \multicolumn{2}{|c|}{$\begin{array}{l}\text { Share prices (YoY } \\
\text { growth, \%) }\end{array}$} & \multicolumn{2}{|c|}{$\begin{array}{l}\text { NEER (YoY } \\
\text { growth, \%) }\end{array}$} & & $\begin{array}{l}\text { TT (YoY } \\
\text { owth, \%) }\end{array}$ & \\
\hline & Mear & SD & & & SD & Mean & SD & Mean & SD & & fean & SD \\
\hline AT & 3.4 & 1.3 & & .4 & 3.5 & 10.1 & 26.0 & 0.3 & 1.9 & & 0.2 & 1.2 \\
\hline $\mathrm{BE}$ & 3.9 & 1.0 & & .4 & 3.7 & 6.3 & 20.6 & 0.6 & 2.5 & & 0.3 & 1.5 \\
\hline $\mathrm{CZ}$ & 4.7 & 1.3 & & 6 & 11.2 & 9.0 & 24.8 & 2.4 & 5.6 & & 0.1 & 1.9 \\
\hline DE & 4.4 & 1.0 & & .2 & 2.9 & 7.1 & 20.2 & 0.6 & 3.2 & & 0.1 & 2.0 \\
\hline DK & 5.1 & 1.4 & & .4 & 8.7 & 10.2 & 21.8 & 0.7 & 2.7 & & 0.5 & 1.4 \\
\hline EE & 2.9 & 1.4 & & .3 & 19.0 & 10.6 & 31.2 & 0.5 & 2.2 & & 0.6 & 1.7 \\
\hline ES & 3.0 & 1.3 & & .1 & 9.5 & 4.0 & 20.5 & 0.5 & 2.2 & & 0.1 & 2.4 \\
\hline FI & 2.5 & 1.3 & & 2 & 3.6 & 4.9 & 20.6 & 0.8 & 2.8 & & 0.7 & 2.2 \\
\hline FR & 3.9 & 0.9 & & .1 & 6.3 & 5.0 & 18.1 & 0.5 & 2.6 & & 0.0 & 1.7 \\
\hline GR & 3.9 & 1.1 & & & 7.4 & -1.3 & 32.0 & 0.7 & 2.3 & & 0.3 & 2.4 \\
\hline $\mathrm{HU}$ & 4.9 & 1.2 & & .4 & 8.1 & 12.6 & 29.4 & -1.5 & 5.3 & & 0.3 & 1.4 \\
\hline IE & 3.3 & 0.8 & & .9 & 12.5 & 5.9 & 24.0 & 0.9 & 4.0 & & 0.6 & 2.6 \\
\hline
\end{tabular}


Table 4 (continued)

\begin{tabular}{|c|c|c|c|c|c|c|c|c|c|c|}
\hline \multirow[t]{3}{*}{ ID } & \multicolumn{2}{|l|}{7} & \multicolumn{2}{|l|}{8} & \multicolumn{2}{|l|}{9} & \multicolumn{2}{|l|}{10} & \multicolumn{2}{|l|}{11} \\
\hline & \multicolumn{2}{|c|}{$\begin{array}{l}\text { Lending rate } \\
\text { housing loans } \\
(\% \text { pa) }\end{array}$} & \multicolumn{2}{|c|}{$\begin{array}{l}\text { Property prices } \\
\text { (YoY growth, \%) }\end{array}$} & \multicolumn{2}{|c|}{$\begin{array}{l}\text { Share prices (YoY } \\
\text { growth, \%) }\end{array}$} & \multicolumn{2}{|c|}{$\begin{array}{l}\text { NEER (YoY } \\
\text { growth, \%) }\end{array}$} & \multicolumn{2}{|c|}{$\begin{array}{l}\text { ToT (YoY } \\
\text { growth, \%) }\end{array}$} \\
\hline & Mean & SD & Mean & SD & Mean & SD & Mean & SD & Mean & SD \\
\hline IT & 3.7 & 1.1 & 0.9 & 4.3 & 2.2 & 19.8 & 0.6 & 2.7 & -0.1 & 2.8 \\
\hline LV & 3.4 & 1.3 & 3.5 & 17.5 & 8.4 & 27.5 & 0.5 & 1.8 & 0.8 & 3.4 \\
\hline NL & 4.5 & 0.6 & 1.8 & 4.7 & 4.2 & 19.3 & 0.6 & 2.9 & -0.1 & 1.0 \\
\hline NO & 4.0 & 1.2 & 6.1 & 4.8 & 15.8 & 25.3 & -0.9 & 5.5 & 2.2 & 10.1 \\
\hline PL & 5.3 & 1.3 & 6.9 & 19.7 & 9.0 & 26.3 & 0.0 & 7.5 & 0.3 & 2.7 \\
\hline PT & 2.8 & 1.5 & 1.2 & 5.2 & 5.6 & 20.2 & 0.4 & 1.3 & 0.4 & 2.1 \\
\hline SE & 3.1 & 1.1 & 6.5 & 5.1 & 9.1 & 20.0 & -0.5 & 5.4 & -0.1 & 1.0 \\
\hline SK & 4.5 & 1.3 & 5.5 & 11.4 & -0.7 & 16.2 & 2.1 & 4.4 & -0.8 & 0.9 \\
\hline SL & 3.4 & 1.4 & 0.3 & 6.7 & -5.0 & 22.2 & 0.3 & 1.5 & -0.1 & 2.1 \\
\hline UK & 4.2 & 1.3 & 5.5 & 7.0 & 1.9 & 14.3 & -1.2 & 6.1 & 0.5 & 1.7 \\
\hline
\end{tabular}

For exact definitions and data sources, see Table 1

Table 5 Cumulative percentage of the variance explained by individual factors

\begin{tabular}{|c|c|c|c|c|c|c|}
\hline & \multicolumn{3}{|c|}{ Estimation with growth rates } & \multicolumn{3}{|c|}{ Estimation with gaps } \\
\hline & F1 $(\%)$ & $\mathrm{F} 2(\%)$ & F3 $(\%)$ & $\mathrm{F} 1(\%)$ & $\mathrm{F} 2(\%)$ & $\mathrm{F} 3(\%)$ \\
\hline AT & 41 & 65 & 81 & 41 & 68 & 86 \\
\hline $\mathrm{BE}$ & 46 & 66 & 78 & 45 & 73 & 92 \\
\hline $\mathrm{CZ}$ & 39 & 66 & 81 & 44 & 73 & 88 \\
\hline $\mathrm{DE}$ & 53 & 67 & 80 & 46 & 71 & 85 \\
\hline DK & 30 & 53 & 73 & 35 & 59 & 74 \\
\hline $\mathrm{EE}$ & 34 & 58 & 76 & 31 & 58 & 79 \\
\hline ES & 46 & 67 & 83 & 44 & 72 & 92 \\
\hline FI & 28 & 50 & 67 & 39 & 63 & 79 \\
\hline FR & 37 & 68 & 83 & 34 & 57 & 81 \\
\hline GR & 40 & 65 & 80 & 45 & 64 & 81 \\
\hline $\mathrm{HU}$ & 36 & 59 & 73 & 49 & 74 & 89 \\
\hline IE & 28 & 53 & 74 & 44 & 63 & 79 \\
\hline IT & 47 & 65 & 82 & 39 & 67 & 84 \\
\hline LV & 38 & 67 & 86 & 42 & 66 & 85 \\
\hline NL & 40 & 67 & 83 & 38 & 74 & 84 \\
\hline NO & 38 & 63 & 77 & 37 & 69 & 83 \\
\hline PL & 32 & 56 & 73 & 46 & 72 & 86 \\
\hline PT & 33 & 57 & 71 & 45 & 68 & 80 \\
\hline SE & 41 & 64 & 77 & 58 & 80 & 92 \\
\hline SK & 46 & 68 & 84 & 48 & 65 & 80 \\
\hline SL & 43 & 68 & 82 & 38 & 64 & 88 \\
\hline UK & 38 & 61 & 72 & 35 & 65 & 83 \\
\hline
\end{tabular}


Table 6 Correlations

\begin{tabular}{|c|c|c|c|c|c|}
\hline & $\begin{array}{l}\text { HOME index } \\
\text { growth }(\mathrm{t}) \text { versus } \\
\text { CCI }(\mathrm{t})\end{array}$ & $\begin{array}{l}\text { HOME index } \\
\text { growth }(t+4) \\
\text { versus CCI }(t)\end{array}$ & $\begin{array}{l}\text { HOME index gap } \\
\text { (t) versus CCI }(t)\end{array}$ & $\begin{array}{l}\text { HOME index gap } \\
(\mathrm{t}+4) \text { versus } \\
\mathrm{CCI}(\mathrm{t})\end{array}$ & $\begin{array}{l}\text { HOME index } \\
\text { growth }(\mathrm{t}) \text { versus } \\
\text { HOME index } \\
\text { gap }(\mathrm{t})\end{array}$ \\
\hline AT & $\begin{array}{l}0.51 * * * \\
(4.63)\end{array}$ & $\begin{array}{l}0.56 * * * \\
(5.35)\end{array}$ & $\begin{array}{l}0.09 \\
(0.75)\end{array}$ & $\begin{array}{l}0.60 * * * \\
(5.95)\end{array}$ & $\begin{array}{l}0.47 * * * \\
(4.24)\end{array}$ \\
\hline $\mathrm{BE}$ & $\begin{array}{l}0.25 * * \\
(2.01)\end{array}$ & $\begin{array}{l}0.66 * * * \\
(6.85)\end{array}$ & $\begin{array}{l}-0.11 \\
(-0.89)\end{array}$ & $\begin{array}{l}0.46^{* * * *} \\
(4.10)\end{array}$ & $\begin{array}{l}0.62 * * * \\
(6.21)\end{array}$ \\
\hline $\mathrm{CZ}$ & $\begin{array}{l}0.79 * * * \\
(10.63)\end{array}$ & $\begin{array}{l}0.76 * * * \\
(9.36)\end{array}$ & $\begin{array}{l}0.61 * * * \\
(6.17)\end{array}$ & $\begin{array}{l}0.71 * * * \\
(8.12)\end{array}$ & $\begin{array}{l}0.79 * * * \\
(10.51)\end{array}$ \\
\hline DK & $\begin{array}{l}0.49 * * * \\
(4.63)\end{array}$ & $\begin{array}{l}0.21^{*} \\
(1.70)\end{array}$ & $\begin{array}{l}-0.06 \\
(-0.50)\end{array}$ & $\begin{array}{l}0.61 * * * \\
(6.26)\end{array}$ & $\begin{array}{l}-0.20 * \\
(-1.69)\end{array}$ \\
\hline $\mathrm{EE}$ & $\begin{array}{l}0.78 * * * \\
(9.08)\end{array}$ & $\begin{array}{l}0.46 * * * \\
(3.65)\end{array}$ & $\begin{array}{l}0.22 \\
(1.63)\end{array}$ & $\begin{array}{l}0.83 * * * \\
(10.97)\end{array}$ & $\begin{array}{l}0.13 \\
(0.89)\end{array}$ \\
\hline FI & $\begin{array}{l}0.41 * * * \\
(3.49)\end{array}$ & $\begin{array}{l}0.57 * * * \\
(5.39)\end{array}$ & $\begin{array}{l}0.03 \\
(0.23)\end{array}$ & $\begin{array}{l}0.45 * * * \\
(3.97)\end{array}$ & $\begin{array}{l}0.66 * * * \\
(7.01)\end{array}$ \\
\hline FR & $\begin{array}{l}0.58 * * * \\
(5.54)\end{array}$ & $\begin{array}{l}0.58 * * * \\
(5.63)\end{array}$ & $\begin{array}{l}0.22 * \\
(1.73)\end{array}$ & $\begin{array}{l}0.30 * * \\
(2.51)\end{array}$ & $\begin{array}{l}0.77 * * * \\
(9.36)\end{array}$ \\
\hline $\mathrm{DE}$ & $\begin{array}{l}0.79 * * * \\
(10.37)\end{array}$ & $\begin{array}{l}0.87 * * * \\
(13.80)\end{array}$ & $\begin{array}{l}0.56^{* * * *} \\
(5.32)\end{array}$ & $\begin{array}{l}0.71 * * * \\
(8.04)\end{array}$ & $\begin{array}{l}0.83 * * * \\
(11.78)\end{array}$ \\
\hline GR & $\begin{array}{l}0.85 * * * \\
(12.82)\end{array}$ & $\begin{array}{l}0.65 * * * \\
(6.84)\end{array}$ & $\begin{array}{l}-0.15 \\
(-1.25)\end{array}$ & $\begin{array}{l}-0.20 * \\
(-1.67)\end{array}$ & $\begin{array}{l}-0.03 \\
(-0.27)\end{array}$ \\
\hline $\mathrm{HU}$ & $\begin{array}{l}0.69 * * * \\
(6.95)\end{array}$ & $\begin{array}{l}0.67 * * * \\
(6.93)\end{array}$ & $\begin{array}{l}0.13 \\
(0.97)\end{array}$ & $\begin{array}{l}0.37 * * * \\
(2.92)\end{array}$ & $\begin{array}{l}0.69 * * * \\
(7.13)\end{array}$ \\
\hline IE & $\begin{array}{l}0.78 * * * \\
(9.92)\end{array}$ & $\begin{array}{l}0.53 * * * \\
(4.93)\end{array}$ & $\begin{array}{l}0.53 * * * \\
(4.89)\end{array}$ & $\begin{array}{l}0.65 * * * \\
(6.72)\end{array}$ & $\begin{array}{l}0.59 * * * \\
(5.85)\end{array}$ \\
\hline IT & $\begin{array}{l}0.58 * * * \\
(5.60)\end{array}$ & $\begin{array}{l}0.66 * * \\
(6.85)\end{array}$ & $\begin{array}{l}-0.03 \\
(-0.27)\end{array}$ & $\begin{array}{l}0.27 * * \\
(2.22)\end{array}$ & $\begin{array}{l}0.14 \\
(1.12)\end{array}$ \\
\hline LV & $\begin{array}{l}0.94 * * * \\
(19.23)\end{array}$ & $\begin{array}{l}0.58 * * * \\
(4.78)\end{array}$ & $\begin{array}{l}-0.04 \\
(-0.30)\end{array}$ & $\begin{array}{l}0.51 * * * \\
(4.22)\end{array}$ & $\begin{array}{l}-0.09 \\
(-0.63)\end{array}$ \\
\hline NL & $\begin{array}{l}0.73 * * * \\
(8.40)\end{array}$ & $\begin{array}{l}0.56^{* * * *} \\
(5.34)\end{array}$ & $\begin{array}{l}0.31 * * \\
(2.60\end{array}$ & $\begin{array}{l}0.77 * * * \\
(9.55)\end{array}$ & $\begin{array}{l}0.51 * * * \\
(4.58)\end{array}$ \\
\hline PL & $\begin{array}{l}0.71 * * * \\
(7.18)\end{array}$ & $\begin{array}{l}0.31 * * \\
(2.32)\end{array}$ & $\begin{array}{l}0.23 * \\
(1.75)\end{array}$ & $\begin{array}{l}0.60 * * * \\
(5.47)\end{array}$ & $\begin{array}{l}0.23 \\
(1.67)\end{array}$ \\
\hline PT & $\begin{array}{l}0.88 * * * \\
(14.78)\end{array}$ & $\begin{array}{l}0.53 * * * \\
(4.94)\end{array}$ & $\begin{array}{l}0.57 * * * \\
(5.40)\end{array}$ & $\begin{array}{l}0.70 * * * \\
(7.82)\end{array}$ & $\begin{array}{l}0.43 * * * \\
(3.71)\end{array}$ \\
\hline SK & $\begin{array}{l}0.82 * * * \\
(10.24)\end{array}$ & $\begin{array}{l}0.66 * * * \\
(6.13)\end{array}$ & $\begin{array}{l}0.71 * * * \\
(7.05)\end{array}$ & $\begin{array}{l}0.79 * * * \\
(9.20)\end{array}$ & $\begin{array}{l}0.86^{* * * *} \\
(11.97)\end{array}$ \\
\hline SL & $\begin{array}{l}0.73 * * * \\
(6.96)\end{array}$ & $\begin{array}{l}0.56^{* * * *} \\
(4.39)\end{array}$ & $\begin{array}{l}0.20 \\
(1.39)\end{array}$ & $\begin{array}{l}0.49 * * * \\
(3.83)\end{array}$ & $\begin{array}{l}0.46^{* * * *} \\
(3.31)\end{array}$ \\
\hline ES & $\begin{array}{l}0.76^{* * * *} \\
(9.26)\end{array}$ & $\begin{array}{l}0.63 * * * \\
(6.43)\end{array}$ & $\begin{array}{l}0.14 \\
(1.07)\end{array}$ & $\begin{array}{l}0.31 * * \\
(2.54)\end{array}$ & $\begin{array}{l}0.33 * * * \\
(2.73)\end{array}$ \\
\hline SE & $\begin{array}{l}0.48 * * * \\
(3.95)\end{array}$ & $\begin{array}{l}0.53 * * * \\
(4.53)\end{array}$ & $\begin{array}{l}-0.06 \\
(0.48)\end{array}$ & $\begin{array}{l}0.71 * * * \\
(7.18)\end{array}$ & $\begin{array}{l}0.70 * * * \\
(7.13)\end{array}$ \\
\hline UK & $\begin{array}{l}0.59 * * * \\
(6.12)\end{array}$ & $\begin{array}{l}0.31 * * * \\
(2.71)\end{array}$ & $\begin{array}{l}-0.03 \\
(-0.25)\end{array}$ & $\begin{array}{l}0.17 \\
(1.41)\end{array}$ & $\begin{array}{l}0.30 * * * \\
(2.66)\end{array}$ \\
\hline
\end{tabular}

T-values in brackets. Statistical significance at the $1 \%, 5 \%$, and $10 \%$ level is indicated by $* * *$, **, and *, respectively 

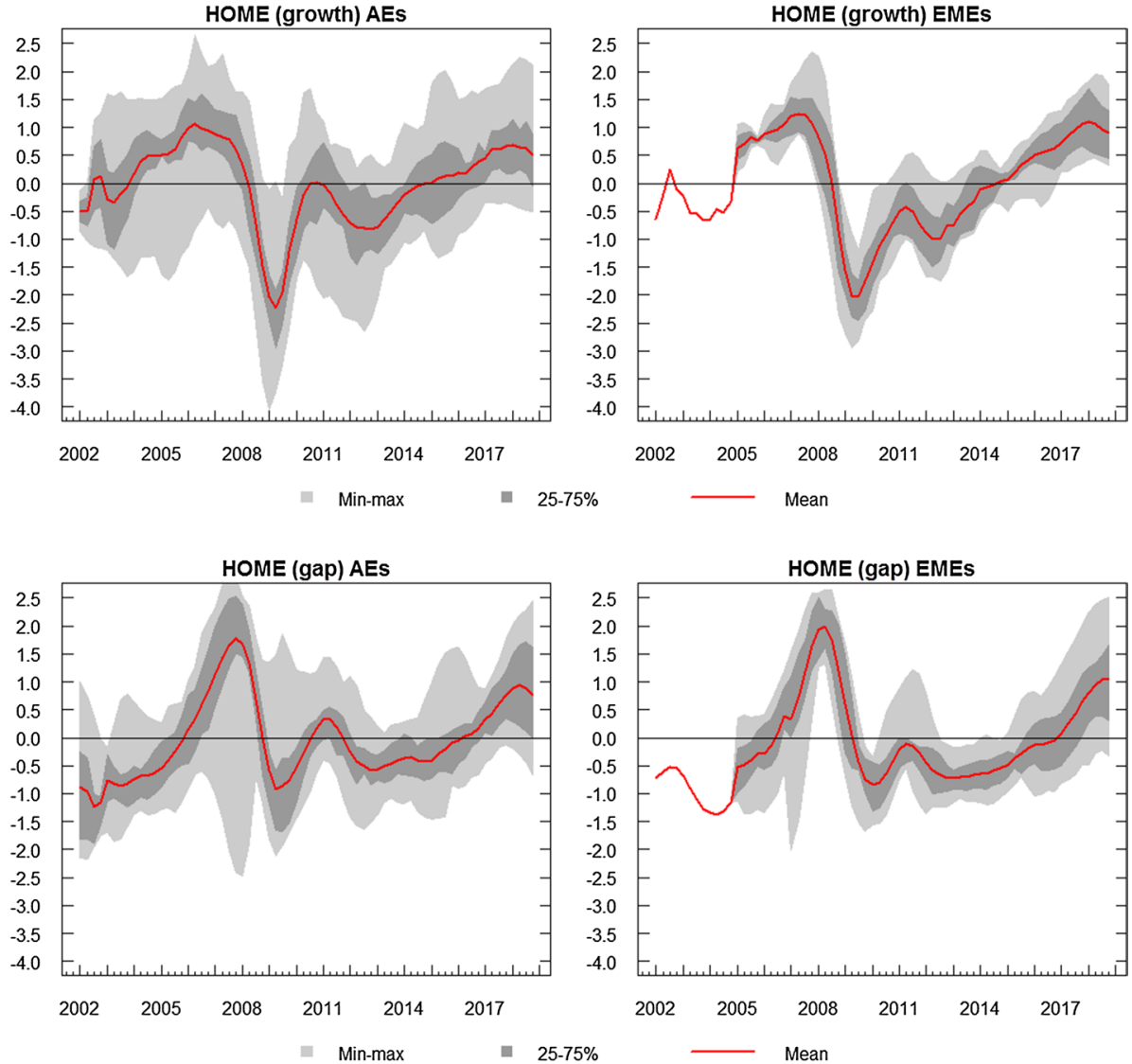

Fig. 6 The HOME Index for selected countries. Note The index is standardized using its long-run mean and standard deviation; the vertical axis shows the standard deviations. The HOME indexes for individual countries are depicted in Figs. 7 and 8 in Appendix 1. AEs-advanced economies as categorized by the IMF for the whole sample period (AT, BE, DE, DK, ES, FI, FR, GR, IE, IT, NL, NO, PT, SE, UK); EMEs-emerging market economies (CZ, EE, HU, LV, PL, SK, SL) 


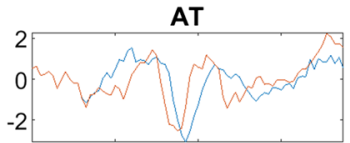

2000:1 2005:1 2010:1 2015:1

DE

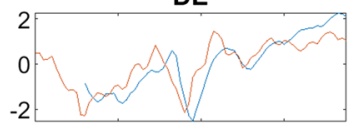

2000:1 2005:1 2010:1 2015:1

ES

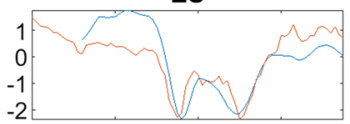

2000:1 2005:1 2010:1 2015:1

GR

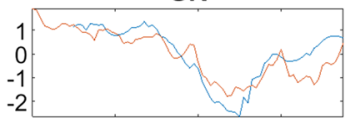

2000:1 2005:1 2010:1 2015:1

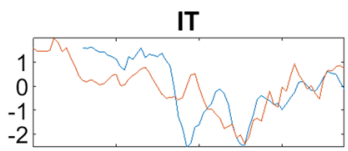

2000:1 2005:1 2010:1 2015:1

NO

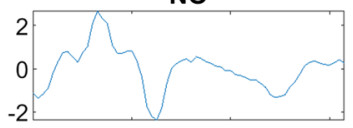

2003:1 2008:1 2013:1 2018:1

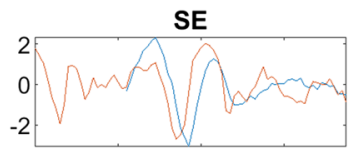

2000:1 2005:1 2010:1 2015:1

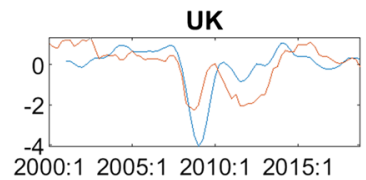

BE

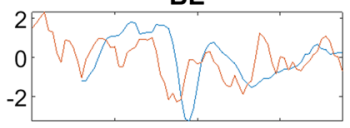

2000:1 2005:1 2010:1 2015:1

DK

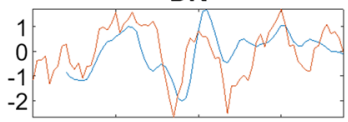

2000:1 2005:1 2010:1 2015:1

FI

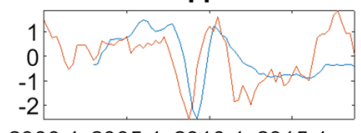

2000:1 2005:1 2010:1 2015:1

HU

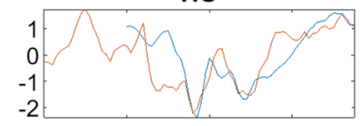

2000:1 2005:1 2010:1 2015:1

LV

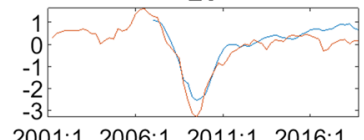

PL

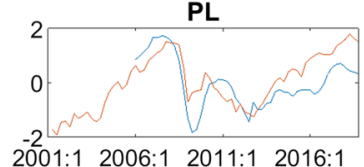

SK

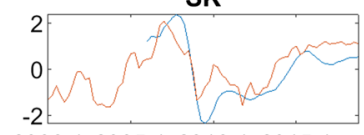

2000:1 2005:1 2010:1 2015:1
CZ

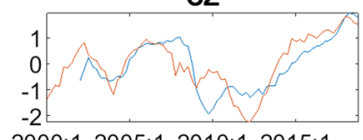

2000:1 2005:1 2010:1 2015:1

EE

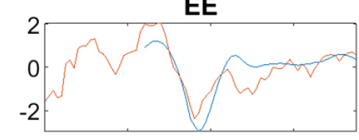

2000:1 2005:1 2010:1 2015:1

FR

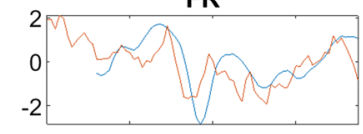

2000:1 2005:1 2010:1 2015:1

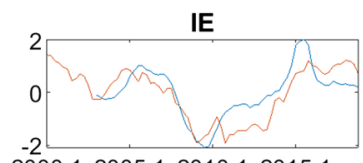

2000:1 2005:1 2010:1 2015:1

NL

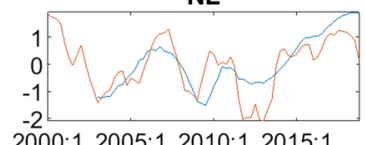

PT

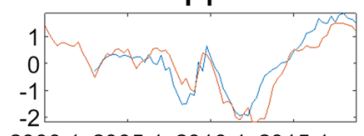

2000:1 2005:1 2010:1 2015:1

SL

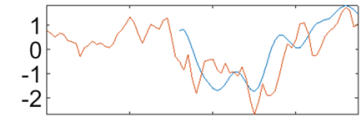

2000:1 2005:1 2010:1 2015:1

HOME (growth) CCI (OECD)

Fig. 7 The HOME Index for Selected European OECD Countries (estimated with annual growth rates). Note The vertical axis reflects the standard deviation. Estimates with three factors 


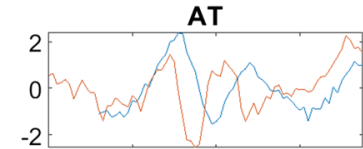

2000:1 2005:1 2010:1 2015:1

DE

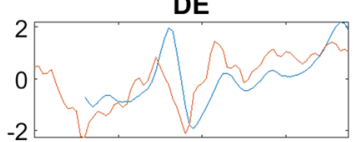

2000:1 2005:1 2010:1 2015:1

ES

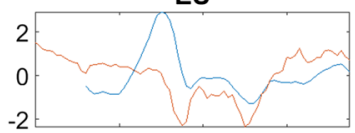

2000:1 2005:1 2010:1 2015:1

GR

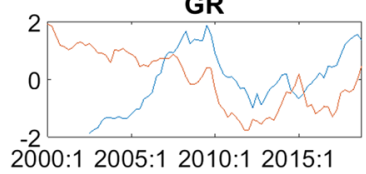

IT

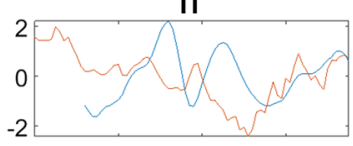

2000:1 2005:1 2010:1 2015:1

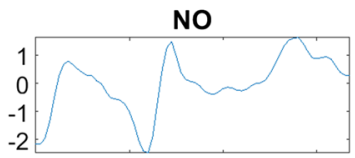

2002:1 2007:1 2012:1 2017:1

SE

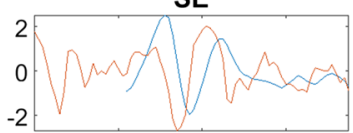

2000:1 2005:1 2010:1 2015:1

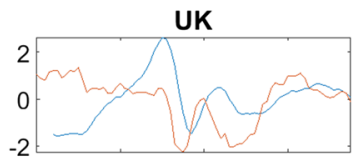

2000:1 2005:1 2010:1 2015:1
BE

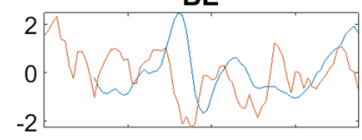

2000:1 2005:1 2010:1 2015:1

DK

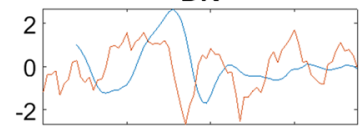

2000:1 2005:1 2010:1 2015:1

FI

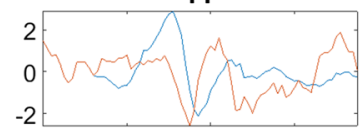

2000:1 2005:1 2010:1 2015:1

HU

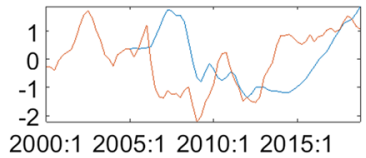

LV

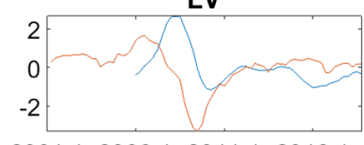

2001:1 2006:1 2011:1 2016:1

PL

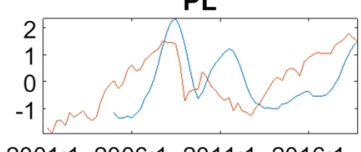

2001:1 2006:1 2011:1 2016:1

SK

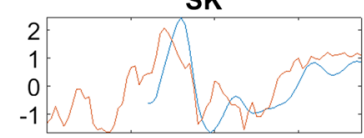

2000:1 2005:1 2010:1 2015:1
CZ

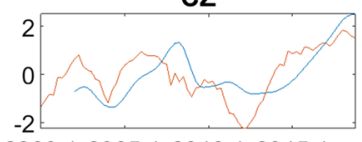

2000:1 2005:1 2010:1 2015:1

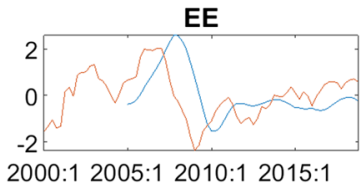

FR

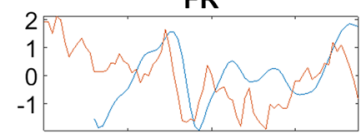

2000:1 2005:1 2010:1 2015:1

IE

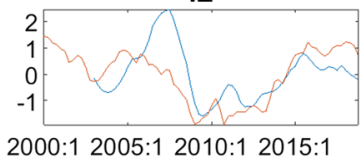

NL
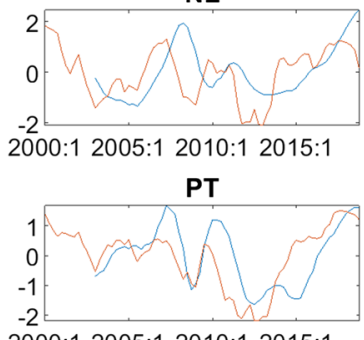

2000:1 2005:1 2010:1 2015:1

SL

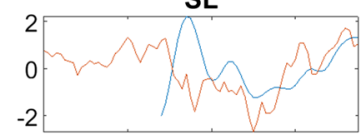

2000:1 2005:1 2010:1 2015:1

HOME (gap) $\mathrm{CCl}(\mathrm{OECD})$

Fig. 8 The HOME Index for Selected European OECD countries (estimated with gaps for selected variables). Note The vertical axis reflects the standard deviation. Estimates with three factors

\section{Appendix 2: Dynamics model averaging}

Given $m$ predictors, the total number of possible combinations of forecasting models is $K=2^{m}$. DMA incorporates the uncertainty factors from these $K=2^{m}$ models as follows: 


$$
\begin{aligned}
& \hat{y}_{t}=\sum_{k=1}^{K} y_{(t \mid \mathrm{t}-1, \mathrm{k})} \\
& z_{t-1}^{(k)^{\prime}} \xi_{t-1}^{(k)},
\end{aligned}
$$

where the probability of model $k$ is $y_{(t \mid \mathrm{t}-1, \mathrm{k})}=\operatorname{Prob}\left(L_{t} \mid Y^{t-1}\right) . L_{t} \in\{1,2, \ldots, K\}$ denotes which model applies in each time period. DMA obtains the forecasting result at any point in time by taking the average of all the $K$ models according to their historical forecasting performances $y_{(t \mid \mathrm{t}-1, \mathrm{k})}$.

The estimation procedure introduced in Raftery et al. (2010) is rather straightforward and is based on the Kalman filter method. The initial assumption is that $\xi_{t-1}^{(k)}$ is independent and identically distributed and can be determined separately only if $L_{t-1}=k$. Raftery et al. (2010) then consider a so-called forgetting factor $\lambda$. The forgetting factor is used to simplify the calculation of $\xi_{t-1}^{(k)}$, where it assigns period $j$ weight $\lambda^{j}$ from the starting period. $\lambda$ is also used to simplify the covariance matrix of $\xi_{t-1}^{(k)}$. The whole process is described as follows:

$$
\begin{gathered}
\xi_{t \mid t-1}^{(k)}=\xi_{t-1 \mid t-1}^{(k)}, \\
\Sigma_{t \mid t-1}^{(k)}=\frac{1}{\lambda} \Sigma_{t-1 \mid t-1}^{(k)},
\end{gathered}
$$

where $\Sigma_{t \mid t-1}^{(k)}$ is the covariance matrix. DMA estimates its parameters by the following equations:

$$
\begin{gathered}
\widehat{\xi}_{t \mid t}^{(k)}=\widehat{\xi}_{t-1 \mid t-1}^{(k)}+\Sigma_{t \mid t-1}^{(k)} z_{t-1}^{(k)^{\prime}}\left(V_{t}^{(k)}+x_{t-1}^{(k)^{\prime}} \Sigma_{t \mid t-1}^{(k)} x_{t-1}^{(k)}\right)^{-1}\left(y_{t}-x_{t-1}^{(k)^{\prime}} \hat{\xi}_{t-1}^{(k)}\right), \\
\Sigma_{t \mid t}^{(k)}=\Sigma_{t \mid t-1}^{(k)}-\Sigma_{t \mid t-1}^{(k)} z_{t-1}^{(k)^{\prime}}\left(V_{t}^{(k)}+x_{t-1}^{(k)^{\prime}} \Sigma_{t \mid t-1}^{(k)} x_{t-1}^{(k)}\right)^{-1} z_{t-1}^{(k)} \Sigma_{t \mid t-1}^{(k)},
\end{gathered}
$$

where Eq. (13) is solved by using the forgetting factor $\lambda$ with $W_{t}^{(k)}=\left(\lambda^{-1}-1\right) \Sigma_{t \mid t-1}^{(k)}$. It is common to choose a value of $\lambda$ near one, suggesting gradual evolution of the coefficients.

A second forgetting factor $\alpha$ is used to reduce the calculation time and error in Eq. (11). If we were to use a transition matrix of probability, we would have to consider $K=2^{m}$ model combinations with $m$ predictors at each time point. For large $m$, the computational burden would be too large. Raftery et al. (2010) suggest replacing the model prediction equation:

$$
y_{t \mid \mathrm{t}-1, \mathrm{k}}=\sum_{l=1}^{K} y_{t-1 \mid \mathrm{t}-1,1} p_{k, l},
$$

with

$$
y_{t \mid \mathrm{t}-1, \mathrm{k}}=\frac{y_{t-1 \mid \mathrm{t}-1, \mathrm{k}}^{\alpha}}{\sum_{l=1}^{K} y_{t-1 \mid \mathrm{t}-1,1}^{\alpha}},
$$

where $\alpha$ is set to a value near one in a similar spirit to that of $\lambda$. In fact, Raftery et al. (2010) indicate that if $\alpha=\lambda=1$, then DMA can be treated as BMA without any forgetting. In 
our application, we follow Raftery et al. (2010) and Koop and Korobilis (2012) and use a constant forgetting factor of $\lambda=\alpha=0.99$ in each period. This means setting a rather noninformative prior over the models $y_{0 \mid 0, \mathrm{k}}=1 / K$ (initially, all models are equally likely) and a relatively diffuse prior on the initial conditions of the states $\xi_{0}^{(k)} \sim N(0,100)$.

\section{Appendix 3: Robustness checks and individual factors for the Czech case study}

The robustness and sensitivity analysis of the selected model specification for calculating the HOME index is performed with respect to the number of factors, the estimation period and the selection of variables. Firstly, a different number of estimated factors does not significantly change the result of the index. Secondly, the index is also robust to shortening the estimation period. Thirdly, the index is robust to variables selection (Figs. 9, 10, 11).

(a) Different number of estimated factors

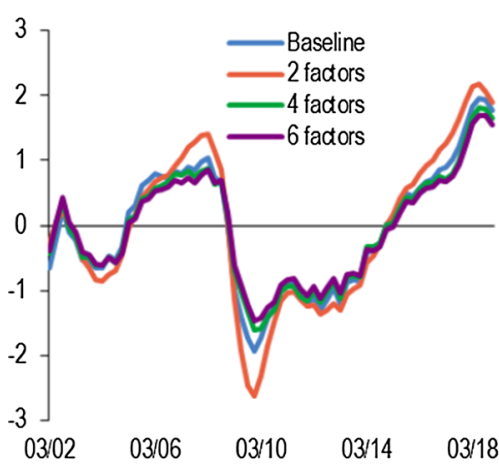

(b) Historical simulations

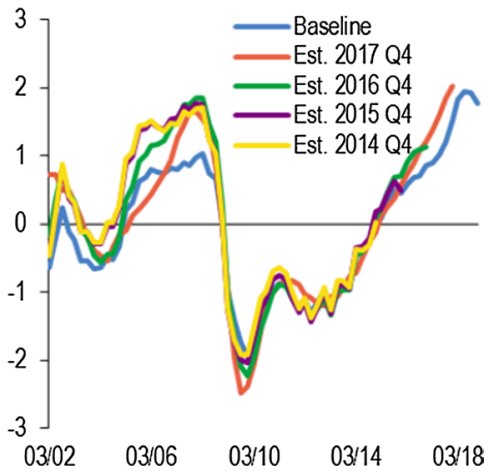

Fig. 9 Robustness checks

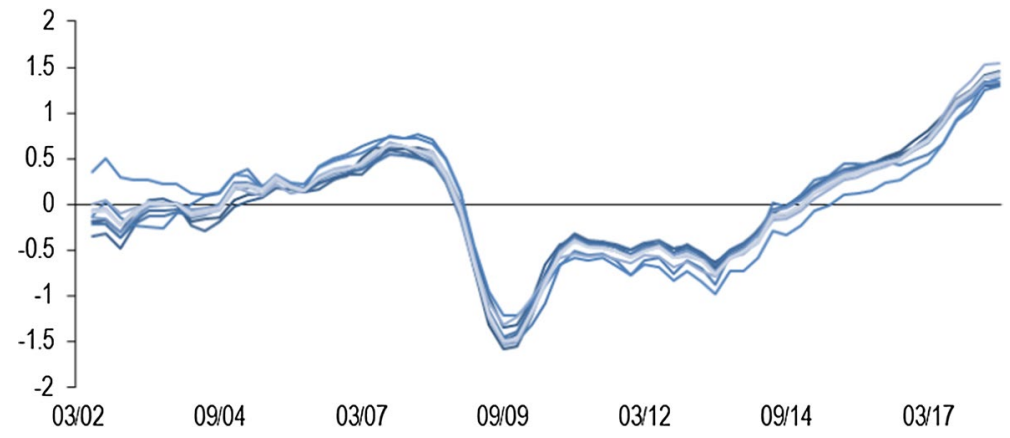

Fig. 10 HOME Index calculated without one variable 
(a) Development of estimated factors

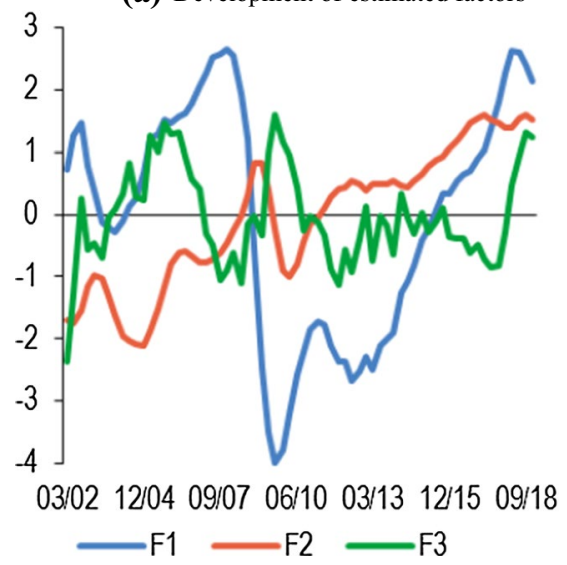

(b) Correlations of estimated factors and underlying data

\begin{tabular}{lllll}
\hline \hline ID & Variable & F1 & F2 & F3 \\
\hline 1 & GDP & $0.81^{* * *}$ & $-0.26^{* *}$ & -0.07 \\
2 & GDI & $0.82^{* * *}$ & -0.13 & $0.36^{* * *}$ \\
3 & GS & 0.12 & -0.10 & $0.78^{* * *}$ \\
4 & Compensation & $0.94^{* * *}$ & -0.12 & -0.09 \\
5 & Employment & $0.65^{* * *}$ & $0.40^{* * *}$ & -0.20 \\
6 & Lending rate CL & $0.59^{* * *}$ & $0.55^{* * *}$ & 0.06 \\
7 & Lending rate HL & 0.17 & $0.89 * * *$ & 0.06 \\
8 & Property prices & $0.72 * * *$ & -0.09 & $-0.50^{* * *}$ \\
9 & Share prices & $0.31^{* *}$ & $-0.61 * * *$ & $0.41^{* * *}$ \\
10 & NEER & $0.60^{* * *}$ & $-0.29 * *$ & -0.09 \\
11 & ToT & -0.06 & -0.12 & $-0.34 * * *$ \\
\hline
\end{tabular}

Fig. 11 Development and correlation analysis of the estimated factors. Note Factors are not standardized. Growth version of the HOME index. Except for lending rates, the data in (b) are in growth rates

Supplementary Information The online version contains supplementary material available at https://doi. org/10.1007/s11205-021-02626-6.

Funding The research was funded by the Czech National Bank under the project FS8/18.

Availability of Data and Materials The underlying data and the resulting index are available for download at the Czech National Bank webpage: https://www.cnb.cz/cs/ekonomicky-vyzkum/publikace-vyzkumu/cnbworking-paper-series/Introducing-a-New-Index-of-Households-Macroeconomic-Conditions/.

Code Availability The underlying code (Matlab) and data are available for download at the Czech National Bank webpage: https://www.cnb.cz/cs/ekonomicky-vyzkum/publikace-vyzkumu/cnb-working-paper-series/ Introducing-a-New-Index-of-Households-Macroeconomic-Conditions/.

\section{Compliance with Ethical Standards}

Conflict of interest All authors are employed by the Czech National Bank.

\section{References}

Acemoglu, S., \& Scott, A. (1994). Consumer confidence and rational expectations: Are agents' beliefs consistent with the theory? Economic Journal, 104(422), 1-19.

Angelico, C. (2019). Household expectations and the credit cycle. Retrieved February 9, 2021, from SSRN: https://ssrn.com/abstract=3491685.

Armstrong, J., Kamber, G., \& Karagedikli, Ö. (2016). Developing a Labour Utilisation Composite Index for New Zealand. Analytical Notes 2016/04, Reserve Bank of New Zealand.

Babecká-Kucharčuková, O., Clayes, P., \& Vašíček, B. (2016). Spillover of the ECB's monetary policy outside the euro area: How different is conventional from unconventional policy? Journal of Policy Modelling, 38(2), 199-225.

Bailey, M., Dávila, E., Kuchler, T., \& Stroebel, J. (2017). House price beliefs and mortgage leverage choice. NBER Working Paper 24091, National Bureau of Economic Research. 
Barnes, M. L., \& Olivei, G. P. (2017). Consumer attitudes and their forecasting power for consumer spending. Journal of Money, Credit and Banking, 49(4), 1031-1058.

Barsky, R. B., \& Sims, E. R. (2012). Information, animal spirits, and the meaning of innovations in consumer confidence. American Economic Review, 102(4), 1343-1377.

Belessiotis, T. (1996). Consumer confidence and consumer spending in France. Economic Papers 116, European Commission.

Benhabib, J., \& Speigel, M. M. (2019). Sentiments and economic activity: Evidence from US States. The Economic Journal, 129(618), 715-733.

Bordalo, P., Gennaioli, N., \& Shleifer, A. (2018). Diagnostic expectations and credit cycles. Journal of Finance, 73(1), 199-227.

Carroll, Ch. D., Fuhrer, J. C., \& Wilcox, D. W. (1994). Does consumer sentiment forecast household spending? If so why? American Economic Review, 84(5), 1397-1408.

Cooper, D., \& Dynan, K. (2016). Wealth effect and macroeconomic dynamics. Journal of Economic Surveys, 30, 34-55.

Coibion, O., Gorodnichenko, Y., \& Weber, M. (2020). The cost of the Covid-19 crisis: Lockdowns, macroeconomic expectations, and consumer spending, NBER Working Papers 27141, National Bureau of Economic Research, Inc.

Chung, H., Fallick, B. C., Nekarda, C. J., \& Ratner, D. (2015). Assessing the change in labor market conditions. Working Paper 1438, Federal Reserve Bank of Cleveland.

Curtin, R. (2007). Consumer sentiment surveys: Worldwide review and assessment. Journal of Business Cycle Measurement and Analysis, 1, 7-42.

De Stefani, A. (2017). Waves of optimism: House price history, biased expectations and credit cycles. ESE Discussion Paper Series, No. 282, Edinburgh School of Economics, University of Edinburgh.

Dees, S., \& Brinca, P. S. (2013). Consumer confidence as a predictor of consumption spending: Evidence for the United States and the euro area. International Economics, 134, 1-14.

Delorme, C., Kamerschen, D., \& Voeks, L. (2001). Consumer confidence and rational expectations in the United States compared with the United Kingdom. Applied Economics, 33, 863-869.

Foote, C., Gerardi, K. S., \& Willen, P. S. (2012). Why did so many people make so many ex post bad decisions? The causes of the foreclosure crisis. NBER Working Paper 18082, National Bureau of Economic Research.

Frait, J., \& Malovaná, S. (2017). Monetary policy and macroprudential policy: Rivals or teammates? Journal of Financial Stability, 32, 1-16.

Fuster, A., Laibson, D., \& Mendel, B. (2010). Natural expectations and macroeconomic fluctuations. Journal of Economic Perspectives, 24(4), 67-84.

Garrett, T. A., Hernández-Murillo, R., \& Owyang, M. T. (2005). Does consumer sentiment predict regional consumption? Federal Reserve Bank of St. Louis Review, 87, 123-135.

Gospodinov, N., \& Ng, S. (2013). Commodity prices, convenience yields, and inflation. The Review of Economics and Statistics, 95(1), 206-219.

Hair, J. F., Black, W. C., Babin, B. J., \& Anderson, R. E. (2012). Multivariate data analysis (7th ed.). Pearson. ISBN 13: 978-1-292-02190-4.

Jiménez, G., Ongena, S., Peydro, J., \& Saurina, J. (2014). Hazardous times for monetary policy: What do twenty-three million bank loans say about the effects of monetary policy on credit risk-taking? Econometrica, 82(2), 463-505.

Jorda, O., Schularick, M., \& Taylor, A. M. (2011). Financial crises, credit booms, and external imbalances: 140 years of lessons. IMF Economic Review, 59, 340-378.

Kłopocka, A. (2017). Does consumer confidence forecast household saving and borrowing behavior? Evidence for Poland. Social Indicators Research, 133(2), 693-717.

Koop, G., \& Korobilis, D. (2011). UK macroeconomic forecasting with many predictors: Which models forecast best and when do they do so? Economic Modelling, 28(5), 2307-2318.

Koop, G., \& Korobilis, D. (2012). Forecasting inflation using dynamic model averaging. International Economic Review, 53(3), 867-886.

Kremer, M., Lo Duca, M., \& Dániel, H.. (2012). CISS-A composite indicator of systemic stress in the financial system. Working Paper Series 1426, European Central Bank.

Kwan, A. C., \& Cotsomitis, J. A. (2006). The usefulness of consumer confidence in forecasting household spending in Canada: A national and regional analysis. Economic Inquiry, 44, 185-197.

Ludvigson, C. (2004). Consumer confidence and consumer spending. Journal of Economic Perspectives, $18(2), 29-50$.

Maddaloni, A., \& Peydró, J.-L. (2013). Monetary policy, macroprudential policy, and banking stability: Evidence from the euro area. International Journal of Central Banking, 9(1), 121-169. 
Mehra, Y. P., \& Martin, E. W. (2003). Why does consumer sentiment predict household spending? Economic Quarterly, 89(Fall), 51-67.

Mishkin, F. S. (1978). Consumer sentiment and spending on durable goods. Brookings Papers on Economic Activity, 1(1978), 217-232.

Nofsinger, J. R. (2012). Household behavior and boom/bust cycles. Journal of Financial Stability, 8(3), $161-173$.

Obstfeld, M., \& Rogoff, K. (2009). Global imbalances and the financial crisis: Products of common causes. CEPR Discussion Papers 7606, Centre for Economic Policy Research.

Peterson, R. A. (2000). A meta-analysis of variance accounted for and factor loadings in exploratory factor analysis. Marketing Letters, 11(3), 261-275.

Raftery, A. E., Karny, M., \& Ettler, P. (2010). Online prediction under model uncertainty via dynamic model averaging: Application to cold rolling mill. Technometrics, 52, 52-56.

Schiller, R. (2000). Measuring bubble expectations and investor confidence. Journal of Psychology and Financial Markets, 1, 49-60.

Souleles, N. S. (2004). Consumer sentiment: Its rationality and usefulness in forecasting expenditureevidence from the Michigan Micro Data. NBER Working Paper 8410, National Bureau of Economic Research.

Van der Zwan, N. (2014). Making sense of financialization. Socio-Economic Review, 12(1), 99-129.

Vanlaer, W., Bielen, S., \& Marneffe, W. (2020). Consumer confidence and household saving behaviors: A cross-country empirical analysis. Social Indicators Research, 147, 677-721.

Vuchelen, J. (2004). Consumer sentiment and macroeconomic forecasts. Journal of Economic Psychology, 25(4), 493-506.

White, W. (2009). Should monetary policy 'Lean or Clean'? Working Paper 34, Federal Reserve Bank of Dallas.

Willis, J. L., \& Hakkio, C. S. (2014). Kansas City Fed's labor market conditions indicators (LMCI). Macro Bulletin, 1-2.

World Bank. (2018a). Doing business 2019 fact sheet: OECD high-income. World Bank. Retrieved December 1, 2019. https://www.doingbusiness.org/content/dam/doingBusiness/media/Fact-Sheets/DB19/ FactSheet_DoingBusiness2019_OECD_Eng.pdf.

World Bank. (2018b). Doing business 2019 regional profile: OECD high income. World Bank. Retrieved December 1, 2019. https://www.doingbusiness.org/content/dam/doingBusiness/media/Profiles/Regio nal/DB2019/OECD-High-Income.pdf.

Publisher's Note Springer Nature remains neutral with regard to jurisdictional claims in published maps and institutional affiliations. 